US Army Corps

of Engineers ${ }_{\circledast}$

Engineer Research and

Development Center

Coastal Inlets Research Program (CIRP)

Performance of Nearshore Berms from

Dredged Sediments: Validation of the Sediment Mobility Tool

Anthony M. Priestas, Brian McFall, and Katherine E. Brutsché

December 2019
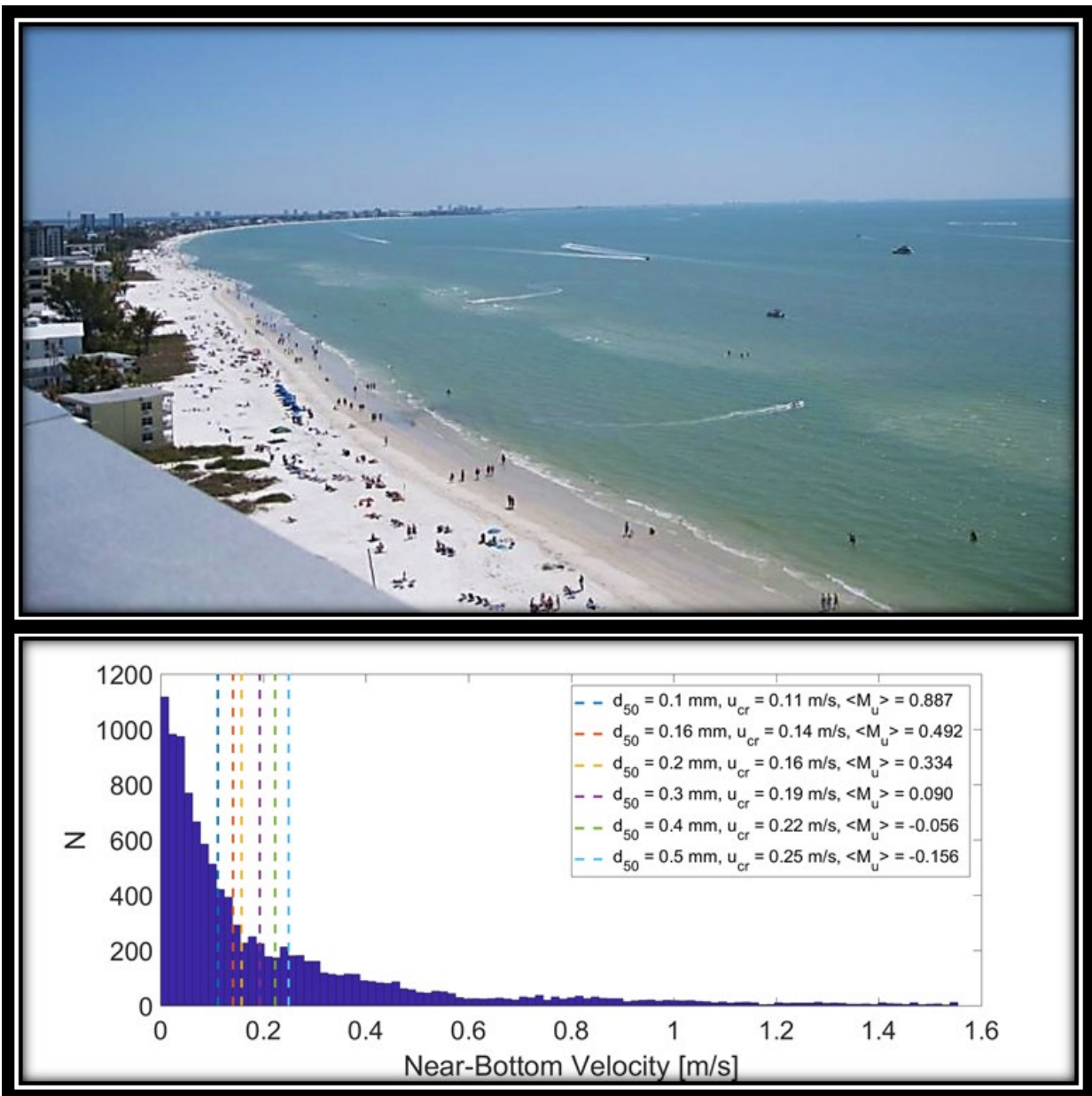
The US Army Engineer Research and Development Center (ERDC) solves the nation's toughest engineering and environmental challenges. ERDC develops innovative solutions in civil and military engineering, geospatial sciences, water resources, and environmental sciences for the Army, the Department of Defense, civilian agencies, and our nation's public good. Find out more at www.erdc.usace.army.mil.

To search for other technical reports published by ERDC, visit the ERDC online library at http://acwc.sdp.sirsi.net/client/default. 


\section{Performance of Nearshore Berms from Dredged Sediments: Validation of the Sediment Mobility Tool}

Anthony M. Priestas, Brian C. McFall, and Katherine E. Brutsché

Coastal and Hydraulics Laboratory

US Army Engineer Research and Development Center

3909 Halls Ferry Road

Vicksburg, MS 39180-6199

Final report

Approved for public release; distribution is unlimited.

Prepared for Coastal Inlets Research Program

US Army Engineer Research and Development Center

3909 Halls Ferry Road

Vicksburg, MS 39180-6199

Under Funding Acct Code U4362900, AMSCO Code 060000 


\section{Abstract}

The construction of artificial berms in the nearshore environment using dredged material has been in practice since the 1930s. While considerable progress has been achieved from both theoretical and practical considerations, placement decisions were often heuristic, based on experience, or required tedious calculations. For that reason, the Sediment Mobility Tool (SMT) was developed to make rapid, preliminary assessments of nearshore placement areas and berm migration.

This technical report provides a comparative analysis between SMT results and historical field observations for nine nearshore placement projects with diverse berm geometries, sediment characteristics, and wave climates.

The SMT correctly predicted nearshore berm sediment mobility and migration directions for eight of the nine historical berms studied. These sites were typically associated with shallow placement depths and energetic wave conditions. Likewise, the SMT correctly predicted stable berms for two of three sites. For one case in particular, the SMT correctly predicted a stable berm in contrast to the expectation that the berm would mobilize, which underscores the value of SMT to make informed decisions during project planning. The few discrepancies between SMT predictions and observations may be partly explained by berm geometry (mound versus linear berm), whereby application of the tool to mounded geometries may not be suitable.

DISCLAIMER: The contents of this report are not to be used for advertising, publication, or promotional purposes. Citation of trade names does not constitute an official endorsement or approval of the use of such commercial products. All product names and trademarks cited are the property of their respective owners. The findings of this report are not to be construed as an official Department of the Army position unless so designated by other authorized documents. 


\section{Contents}

Abstract.............................................................................................................. ii

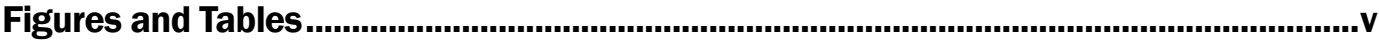

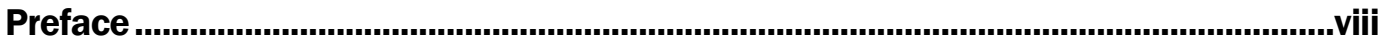

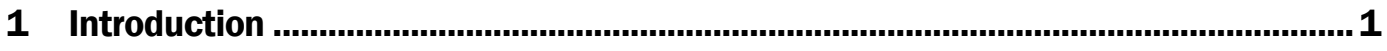

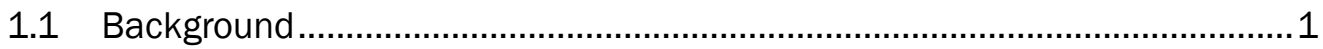

1.2 Methods to Predict Berm Migration ...........................................................

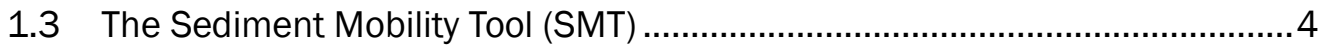

1.3.1 Bed shear stress from linear wave theory ............................................................. 5

1.3.2 Near-bed velocity from non-linear stream function theory ...................................... 6

1.4 Previous applications of the SMT ........................................................ 7

1.5 Objective.......................................................................................... 9

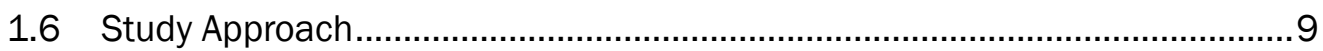

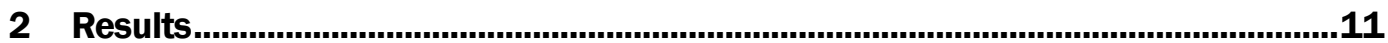

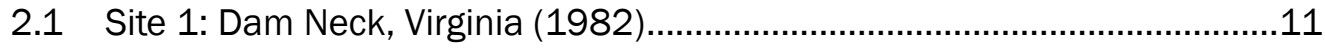

2.1.1 Site description and berm construction ........................................................... 11

2.1.2 Hydrographic description................................................................................ 12

2.1.3 Monitoring and berm evolution ....................................................................... 13

2.1.4 SMT results....................................................................................................... 13

2.2 Site 2: Mobile Outer Mound (MOM), Alabama (1988) ................................15

2.2.1 Site description and berm construction ............................................................ 15

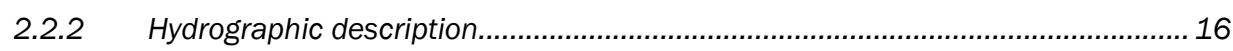

2.2.3 Monitoring and berm evolution ..................................................................... 17

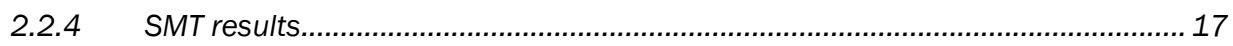

2.3 Site 3: Silver Strand, California (1988) ...................................................19

2.3.1 Site description and berm construction ............................................................ 19

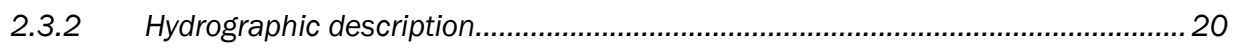

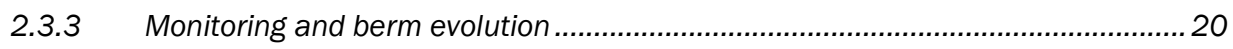

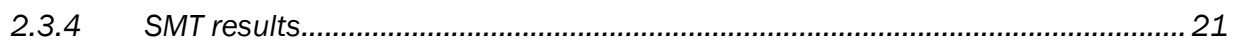

2.4 Site 4: Port Canaveral, Florida (1992) …............................................... 23

2.4.1 Site description and berm construction ........................................................... 23

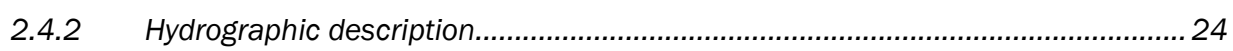

2.4.3 Monitoring and berm evolution ......................................................................... 24

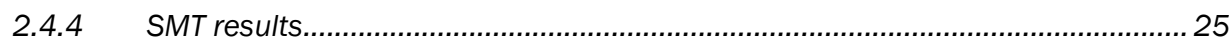

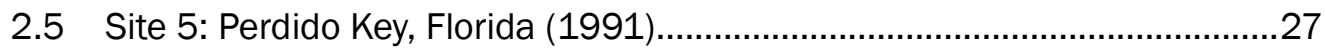

2.5.1 Site description and berm construction ............................................................... 27

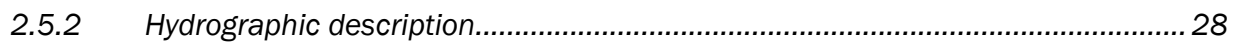

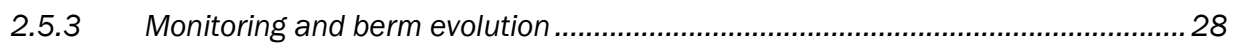

2.5.4 SMT results..................................................................................................... 29

2.6 Site 6: Newport Beach, California (1992) ..................................................31

2.6.1 Site description and berm construction ........................................................... 31 


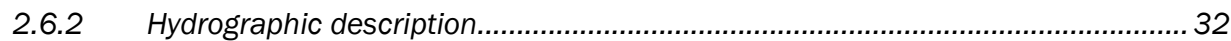

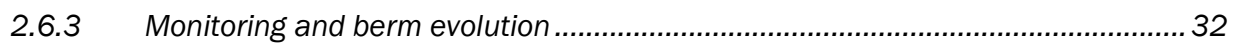

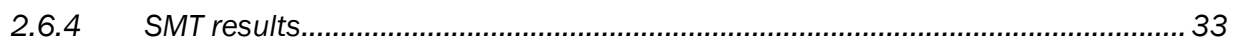

2.7 Site 7: Brunswick, Georgia “Mound C” (2003) .......................................... 35

2.7.1 Hydrographic description.................................................................................. 35

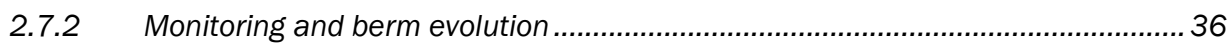

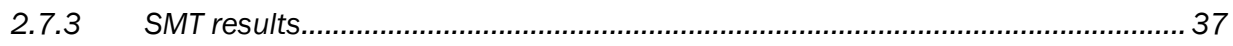

2.8 Site 8: Ocean Beach, California (2005) ….............................................. 39

2.8.1 Site descriptions and berm monitoring ............................................................ 39

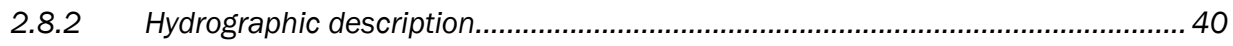

2.8.3 Monitoring and berm evolution ............................................................................. 40

2.8.4 SMT results.............................................................................................................. 40

2.9 Site 9: Fort Meyers Beach, Florida (2009)............................................... 42

2.9.1 Site description and berm construction ......................................................... 42

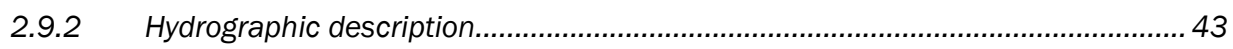

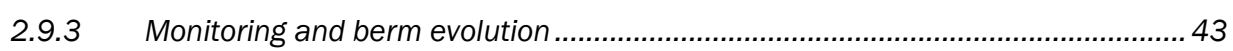

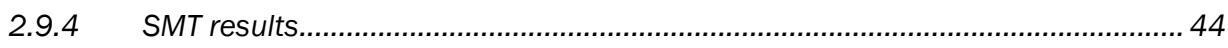

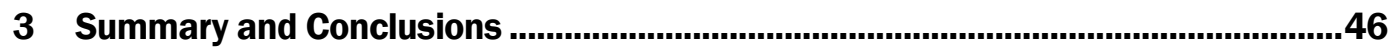

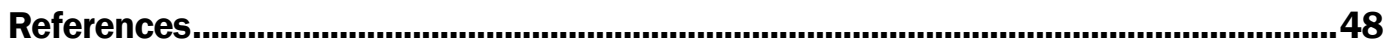

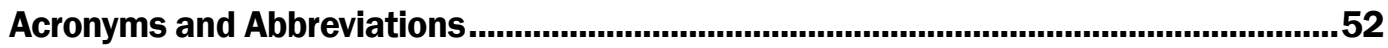

Report Documentation Page 


\section{Figures and Tables}

\section{Figures}

Figure 1-1. Proposed nearshore placement sites for dredged sediment near Milford, CT; Gulf Beach (blue hatched area) and Bayview Beach (red striped area). Soundings in feet. National Oceanic and Atmospheric Administration chart 12370.

Figure 2-1. Location map of placement site Dam Neck, Virginia. Image date 2016.

Figure 2-3. Distribution of maximum bed shear stress (top) and near-bottom velocities (bottom) for site Dam Neck, Virginia (WIS station 63199). $N$ is the number of hourly wave heights in each bin during the monitoring period.

Figure 2-4. Location map of the MOM, Alabama (after Hands et al. [1992]). Image date 2016.

Figure 2-5. Distribution of maximum bed shear stress (top) and near-bottom velocities (bottom) for site MOM, Alabama (WIS station 73153). $N$ is the number of hourly wave heights in each bin during the monitoring period.

Figure 2-6. Location map of Silver Strand placement site, California. Image date 2018.

Figure 2-7. Distribution of maximum bed shear stress (top) and near-bottom velocities (bottom) for site Silver Strand, California (WIS station 83107). $N$ is the number of hourly wave heights in each bin during the monitoring period.

Figure 2-8. Location map of Port Canaveral placement site, Florida. Image date 2016.

Figure 2-9. Distribution of maximum bed shear stress (top) and near-bottom velocities (bottom) for site Port Canaveral, Florida (WIS station 63439). $N$ is the number of hourly wave heights in each bin during the monitoring period.

Figure 2-10. Location map of the 1991 Perdido Key, Florida placement site. Image date 2015

Figure 2-11. Distribution of maximum bed shear stress (top) and near-bottom velocities (bottom) for site Perdido Key (1991), Florida (WIS station 73164). $N$ is the number of hourly wave heights in each bin during the monitoring period.

Figure 2-12. Location map of Newport Beach placement site, California. Image date 2016.

Figure 2-13. Distribution of maximum bed shear stress (top) and near-bottom velocities (bottom) for site Newport Beach, California (WIS station 83102) N is the number of hourly wave heights in each bin during the monitoring period.

Figure 2-14. Location map of placement site Brunswick, Georgia, "Mound C." Image date 2016.

Figure 2-15. Distribution of maximum bed shear stress (top) and near-bottom velocities (bottom) for site Brunswick, Georgia, "Mound C" (WIS station 63393). $N$ is the number of hourly wave heights in each bin during the monitoring period.

Figure 2-16. Location map of placement site Ocean Beach, California. Imagery courtesy of Google Earth. Image date 2016. 
Figure 2-17. Distribution of maximum bed shear stress (top) and near-bottom velocities (bottom) for site Ocean Beach, California (WIS station 83107). $N$ is the number of hourly wave heights in each bin during the monitoring period.

Figure 2-18. Location map of placement site Fort Meyers Beach, Florida. Imagery courtesy of Google Earth. Image date 2016.

Figure 2-19. Distribution of maximum bed shear stress (top) and near-bottom velocities (bottom) for site Fort Meyers, Florida (WIS station 73259). $N$ is the number of waves in each bin during the monitoring period.

\section{Tables}

Table 1-1. Summary of key nearshore berm design guidance documents from the DRP technical notes.

Table 1-2. Historical nearshore berm placement sites used for SMT comparisons in the present study and their primary references..

Table 2-1. Summary characteristics table for Dam Neck, Virginia.

Table 2-2. Dam Neck, Virginia, frequency of mobilization and predicted sediment migration for indicated grain sizes. Median grain size of placed material in bold.

Table 2-3. Summary characteristics table for Mobile Outer Mound, Alabama.

Table 2-4. MOM frequency of mobilization and predicted sediment migration for indicated grain sizes. Median grain size of placed material in bold.

Table 2-5. Summary characteristics table for Silver Strand, California.

Table 2-6. Silver Strand frequency of mobilization and predicted sediment migration for indicated grain sizes. Median grain size of placed material in bold.

Table 2-7. Summary characteristics table for Port Canaveral, Florida.

Table 2-8. Port Canaveral frequency of mobilization and predicted sediment migration for indicated grain sizes. Median grain size of placed material in bold. .26

Table 2-9. Summary characteristics table for Perdido Key, Florida (1991).

Table 2-10. Perdido Key (1991) frequency of mobilization and predicted sediment migration for indicated grain sizes. Median grain size of placed material in bold

Table 2-11. Summary characteristics table for Newport Beach, California.

Table 2-12. Perdido Key (1991) frequency of mobilization and predicted sediment migration for indicated grain sizes. Median grain size of placed material in bold...

Table 2-13. Summary characteristics table for Brunswick, Georgia.

Table 2-14. Brunswick, Georgia frequency of mobilization and predicted sediment migration for indicated grain sizes. Median grain size of placed material in bold.

Table 2-15. Summary characteristics table for Ocean Beach, California. Asterisks indicate values derived from WIS data over the indicated monitoring period

Table 2-16. Ocean Beach, California frequency of mobilization and predicted sediment migration for indicated grain sizes. The median grain size of placed material is shown in bold.

Table 2-17. Summary characteristics table for Fort Meyers Beach, Florida. 
Table 2-18. Fort Meyers Beach, Florida frequency of mobilization and predicted sediment migration for indicated grain sizes. Median grain size of placed material

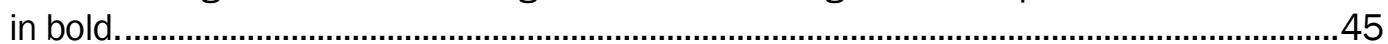

Table 3-1. Summary of SMT berm migration results compared to observations...............47 


\section{Preface}

This study was sponsored by the Coastal Inlets Research Program (CIRP), under the "Inlet Geomorphological Evolution" work unit, Funding Acct Code U4362900, AMSCO Code 060000. The CIRP is funded by the Operation and Maintenance Navigation Business Line of the Headquarters, U.S. Army Corps of Engineers (HQUSACE), and is administered by the U.S. Army Engineer Research and Development Center (ERDC), Coastal and Hydraulics Laboratory (CHL), Vicksburg, MS, under the Navigation Program of HQUSACE.

The work was performed by the Coastal Engineering Branch and the Field Data Collection and Analysis Branch of the Navigation Division, ERDC CHL. The Branch Chiefs were Ms. Lauren M. Dunkin and Mr. William C. Butler, respectively, and Dr. Jackie S. Pettway was Chief of the Navigation Division.

At the time of publication of this report, the HQUSACE CIRP Program Manager was Dr. Tanya M. Beck, and Ms. Kathy Griffin was the HQUSACE Navigation Business Line Manager. Mr. Charles E. Wiggins was the ERDC Technical Director for Civil Works and Navigation Research, Development, and Technology Transfer portfolio. The Deputy Director of ERDC-CHL was Mr. Jeffrey R. Eckstein, and the Director of ERDC-CHL was Dr. Ty V. Wamsley.

COL Teresa A. Schlosser was the Commander of ERDC, and the Director was Dr. David W. Pittman. 


\section{Introduction}

\subsection{Background}

The strategic placement of dredged material has been used since at least the 1930 s for beach and littoral zone nourishment and for general shore protection through wave energy reduction. Through the numerous case studies that followed, especially throughout 1980-1990s, much insight was gained to optimize and quantify benefits from nearshore berm placements. Much of this work focused on berm design considerations (McLellan et al. 1988, 1990; McLellan 1990; McLellan and Kraus 1991; Allison and Pollock 1993) and refinements to predict sediment mobility (Hands and Allison 1991; Kraus 1992; Larson and Kraus 1992; Douglass 1995; Ahrens and Hands 1998). Recently, Tyler et al. (2018) offer monitoring guidance to objectively quantify benefits in the field.

Nearshore berms are artificially constructed sand bars placed in the nearshore environment. Their primary purpose is to nourish beaches and reduce sand loss from the regional littoral system (often at reduced cost compared to traditional beach placement) or to protect beaches through reduction of wave energy. Constructed berms do not necessarily have to supply sand to the beach (i.e., feeder berms) to offer benefit or protection from erosion. Similar to underwater breakwaters, stable berms can be built to allow smaller waves to pass while dissipating larger waves due to wave breaking, as was demonstrated in Durban Bay, South Africa (Zwamborn et al. 1970). This management strategy has been utilized since the 1930 and is considered a cost effective way to manage dredged material for beneficial use in accordance with the US Army Corps of Engineers (USACE) Regional Sediment Management program.

The first documented nearshore berm was constructed off the coast of Santa Barbara in 1935. As reported in Hall (1950) 154,000 cubic meters (m3) of material was placed in 6 meters $(\mathrm{m})$ of water (relative to mean lower low water [MLLW]) in an attempt to nourish the beach. One year after placement, the berm was reported to be remarkably stable, having lost the height of its crest by only 30 centimeters $(\mathrm{cm})(10 \%-20 \%$ of the original height). Near this time (1948), a larger-scale project directed by the USACE Philadelphia District attempted to nourish beaches near Atlantic City, 
New Jersey. In this case, 2.7 million $\mathrm{m}^{3}$ were placed in 5-6 $\mathrm{m}$ of water between 1935 and 1942, with similar results to the berm at Santa Barbara.

Another demonstration was completed in 1948 to nourish beaches near the city of Long Branch, New Jersey. In a series of placements totaling $460,000 \mathrm{~m}^{3}$, the berm was constructed to the dimensions of $1,100 \mathrm{~m}$ in length, $450 \mathrm{~m}$ in width, and $2 \mathrm{~m}$ in height, $800 \mathrm{~m}$ offshore in $12 \mathrm{~m}$ of water. The project was well documented, having measured sediment grain size distributions and composition as well as the local wind and wave climate. While it was estimated that there were waves of sufficient size and occurrence capable of moving sediment, it was determined that the berm showed no evidence of substantial movement shoreward; instead, any movement that did occur appeared haphazard (Harris 1954).

Furthermore, the shoreline continued to erode during the same time period. After 10 years of continued monitoring (Hall and Herron 1950; Harris 1954; Hall and Watts 1957) it was concluded that the berms provided no measurable benefit to adjacent shorelines. The re-study by Harris (1954) posited that the material should be placed in less than $6 \mathrm{~m}$ of water and shoreward of the offshore bar to obtain the desired benefits.

Lessons learned from these early attempts gave rise to certain berm design criteria based on dredged material quantity and quality, local wave and current conditions, and available dredging equipment. Previous experience suggests that a berm's length should be several times the average local wavelength, and oriented shore-parallel to avoid wave focusing and refraction effects (Zwamborn et al. 1970; McLellan et al. 1990). Additionally, the ratio of placement depth to berm height depends on whether the berm is intended to function as a stable berm versus feeder berm. For feeder berms, Kraus (1992) suggested they be placed as close to shore as possible. A series of additional guidelines were published within Dredging Research Program (DRP) technical notes between 1990 and 1993, which is summarized in Table 1-1.

Table 1-1. Summary of key nearshore berm design guidance documents from the DRP technical notes.

\begin{tabular}{|l|l|}
\hline Technical Note & Key Design Guidance \\
\hline $\begin{array}{l}\text { DRP-5-01 } \\
\text { (McLellan 1990) }\end{array}$ & $\begin{array}{l}\text { Recommended a linear berm rather than a conical } \\
\text { berm to prevent wave focusing. }\end{array}$ \\
\hline $\begin{array}{l}\text { DRP-5-02 } \\
\text { (McLellan et al. 1990) }\end{array}$ & $\begin{array}{l}\text { Discussed methods to determine the seaward limit of } \\
\text { the littoral zone for active berm placement. }\end{array}$ \\
\hline
\end{tabular}




\begin{tabular}{|l|l|}
\hline Technical Note & Key Design Guidance \\
\hline $\begin{array}{l}\text { DRP-5-06 } \\
\text { (Burke and Allison 1992) }\end{array}$ & $\begin{array}{l}\text { Recommended minimum longshore length of } 610 \mathrm{~m} \\
\text { with end slopes of 1V:125H to prevent wave focusing. }\end{array}$ \\
\hline $\begin{array}{l}\text { DRP-5-08 } \\
\text { (Pollock and Allison } \\
\text { 1993) }\end{array}$ & $\begin{array}{l}\text { Recommended minimum berm crest width, } b_{c} \text {, of } 61 \mathrm{~m} \\
\text { to reduce wave height. }\end{array}$ \\
\hline
\end{tabular}

During the 1980s-1990s, the prediction of berm movement was developed using the methods of Hallermeier (1981b), Larson et al. (1989), and Ahrens and Hands (1998). The methods use the concepts of depth of closure, linear wave theory, and non-linear stream function wave theory to determine the thresholds of sediment movement. However, there was no rapid way to assess the likelihood of sediment mobility without first collecting relevant data and performing the calculations. To that end, the SMT was developed to perform those calculations within a simple, userfriendly online tool. Therefore, the SMT allows planners and engineers to make sound, preliminary judgments on placement options quickly with little effort or expense. A user's guide for the SMT can be found in McFall and Brutsché (2018).

To access the SMT, visit http://navigation.usace.army.mil/SEM/SedimentMobility.

\subsection{Methods to predict berm migration}

Larson et al. (1989) developed a method using the Dean number to predict cross-shore sediment movement based on berm placement depth and hindcasted wave parameters. The berm placement depth is assessed using offshore profile data, or in the absence of profile data, Hallermeier's (1981) closure depth equation for the inner limit, $h_{i n}$, given as

$$
h_{\text {in }}=2.28 H_{e}-68.5\left(\frac{H_{e}^{2}}{g T_{e}^{2}}\right) \approx 1.6 H_{e}
$$

where $H_{e}$ is the effective (or exceedance) wave height, $T_{e}$ is its associated wave period, and $g$ is the acceleration due to gravity. The effective wave is defined as the deep water wave height exceeded 12 hours per year, estimated using the statistical relation given by Hallermeier (1981b),

$$
H_{e}=\overline{H_{S}}+5.6 \sigma_{H}
$$


where $\overline{H_{S}}$ is the mean significant wave height and $\sigma_{H}$ is the standard deviation of the wave record.

Berm placements at depths less than $h_{i n}$ are conducive to wave breaking and more likely to become part of the littoral zone (feeder berm). Once the minimum placement depth is determined, the direction of movement is assessed via wave steepness $\left(H_{o} / L_{o}\right)$ and the Dean number, or dimensionless fall speed $\left(H_{o} / w T\right)$, using the relation,

$$
\frac{H_{O}}{L_{o}}=M\left(\frac{H_{O}}{w T}\right)^{3}
$$

where $H_{o}$ is the deep water wave height (m), $L_{o}$ is the deep water wave length (m), $T$ is the peak spectral wave period (m), $w$ is the sediment fall speed (meters per second) in still water, and $M$ is an empirically determined coefficient (Larson et al. 1989). If the wave steepness is greater than the right hand side of Equation (3) then sediment is predicted to move onshore; the converse is predicted if the wave steepness is less than the right side. However, using a large, worldwide data set of cross-shore profiles, Kraus (1992) showed an even simpler dependence on the Dean number to predict cross-shore sediment movement for a range of grain sizes:

$$
\begin{aligned}
& \frac{H_{O}}{w T}<7.2, \text { onshore } \\
& \frac{H_{O}}{w T}>7.2, \text { offshore }
\end{aligned}
$$

\subsection{The Sediment Mobility Tool (SMT)}

The SMT was developed as a means to quickly assess the likelihood and direction of sediment mobility as a function of grain size, placement depth, and local hydrodynamic and wave conditions. Specifically, the tool predicts the frequency and primary direction of sediment mobility for a suite of grain sizes at a single depth. The SMT automates the calculations based on user input and queried data, including Wave Information Studies (WIS) data, which are directly imported into the SMT for the specified duration. Other user inputs to the SMT include water depth at the site of data collection, shoreline orientation, median grain size, and the longshore current velocity (assumed or measured) $1 \mathrm{~m}$ above the bed. For the sites tested in this technical report, Gulf and Atlantic sites assumed a longshore current velocity value of 0.05 meter per second (m/s) while for Pacific 
sites, a value of $0.1 \mathrm{~m} / \mathrm{s}$ was used. These are reasonable assumptions based on general field and laboratory observations (Galvin and Nelson 1967) while recognizing the variability due to breaking wave height and angle, slope, and the distribution with offshore distance.

The SMT adds to the methodology of Larson and Kraus (1989) in that it also estimates the percent frequency of mobility and provides a range of sediment mobility based on two calculation methods. The first method calculates the maximum local wave- and current-induced bed shear stress derived from standard linear wave theory (Soulsby 1997; Myrhaug 1989), which is then compared to the critical threshold of movement (Shields' parameter) for various median grain diameters. The second calculates the maximum near-bed wave orbital velocity from non-linear stream function wave theory (Dean 1974; Ahrens and Hands 1998), which is then compared to critical velocity conditions for various median grain diameters. The cross-shore migration direction is calculated using Dean's number (Equation 4). Wave direction at the nearshore site is displayed as a wave rose with resultant vector direction indicating the axis of wavedominated sediment transport. This is accomplished by transforming the wave conditions from the offshore WIS station to the nearshore placement site using the conservation of energy flux and Snell's Law, assuming shoreparallel depth contours. An overview of the calculations used in the SMT is described here briefly; more detail on SMT methodology can be found in McFall et al. (2016).

\subsubsection{Bed shear stress from linear wave theory}

The critical shear stress $\left(\tau_{c r}\right)$ to initiate sediment movement is calculated using the well-known Shields criterion $\left(\theta_{c r}\right)$, which is the ratio of the fluid force to the submerged weight of the particle,

$$
\tau_{c r}=\theta_{c r} g\left(\rho_{s}-\rho\right) d_{50}
$$

where $g$ is gravitational acceleration, $\rho_{s}$ is sediment density, $\rho$ is water density, and $d_{50}$ is the median grain diameter. The wave-induced shear stress $\left(\tau_{w}\right)$ is calculated as,

$$
\tau_{w}=\frac{1}{2} \rho f_{w} U_{w}^{2}
$$


where $f_{w}$ is the wave friction factor and $U_{w}$ is the bottom wave orbital velocity determined by the procedure of Soulsby (1997). The currentinduced shear stress $\left(\tau_{c}\right)$ is calculated using the law of the wall formulation given by,

$$
\tau_{c}=\left(\frac{\bar{U} \kappa}{\ln \left(\frac{z}{z_{o}}\right)}\right)^{2}
$$

where $\bar{U}$ is the estimated mean current velocity, $\kappa$ is von Karman's constant $(\kappa=0.4), z$ is the height of the current velocity above the bed (assumed $z=1.0 \mathrm{~m}$ ), and $z_{o}$ is the bed roughness length (for flat sand, $z_{o}=$ $\left.d_{50} / 12\right)$.

The maximum bed shear stress $\left(\tau_{\max }\right)$, determined from the mean bed shear stress $\left(\tau_{m}\right)$ and the angle between the wave and current directions, is calculated as

$$
\tau_{\max }=\left[\left(\tau_{m}+\tau_{w} \cos \phi\right)^{2}+\left(\tau_{w} \sin \phi\right)^{2}\right]^{1 / 2}
$$

for

$$
\tau_{m}=\tau_{c}\left[1+1.2\left(\frac{\tau_{w}}{\tau_{c}+\tau_{w}}\right)^{3.2}\right]
$$

The frequency of mobility $\left(f_{M}\right)$ for a specified grain diameter is expressed as the fraction of waves whereby the maximum shear stress exceeds the critical threshold. The mean mobility score $(M)$ is then the time-averaged and normalized difference between the bottom shear stress and the critical threshold for a specified grain diameter, calculated as,

$$
M=\left(\frac{\overline{\tau_{\max }-\tau_{c r}}}{\tau_{c r}}\right)
$$

Sites with negative mobility scores indicate that the averaged maximum bed shear stress is less than the critical shear stress.

\subsubsection{Near-bed velocity from non-linear stream function theory}

The critical near-bottom velocities required to mobilize sediment are calculated using Ahrens and Hands (1998), 


$$
u_{c r}=\left[8 g_{\gamma d_{50}}\right]^{1 / 2} \text { for } d_{50} \leq 2.0 \mathrm{~mm}
$$

where $\gamma=\left(\rho_{s}-\rho_{w}\right) / \rho_{w}$ and $\rho_{s}, \rho_{w}$ are the respective sediment and water densities. The maximum near-bed wave orbital velocities for the crest and trough phases are calculated using stream function wave theory (Ahrens and Hands 1998),

$$
u_{\text {maxcrest }}=\left(\frac{H}{T}\right)\left(\frac{h}{L_{o}}\right)^{-0.579} \exp \left[0.289-0.491\left(\frac{H}{h}\right)-2.97\left(\frac{h}{L_{o}}\right)\right]
$$

and

$$
u_{\text {maxtrough }}=\left(\frac{H}{T}\right) \exp \left[1.966-6.70\left(\frac{h}{L_{o}}\right)-1.73\left(\frac{H}{h}\right)+5.58\left(\frac{H}{L_{o}}\right)\right]
$$

where $H$ is the wave height at the placement site, $T$ is its wave period, $h$ is the water depth at the placement site, and $L_{o}=g T^{2} / 2 \pi$ is the offshore wavelength. The absolute maximum near-bed velocity is selected from $u_{\text {max }}=\max \left(\left|u_{\text {maxcrest }}\right|,\left|u_{\text {maxtrough }}\right|\right)$. Stream function theory is appropriate for water depths in the range $0.006 \mathrm{gT}^{2}$ to $0.016 \mathrm{gT}^{2}$ (Soulsby 1997).

Similar to the previous method, the frequency of mobility $f_{M u}$ is expressed as the fraction of waves whereby the maximum near-bed velocity exceeds the critical threshold. The respective mean mobility score $\left(M_{u}\right)$ is the timeaveraged and normalized difference between the maximum bottom velocity and the critical velocity for a specified grain diameter, calculated as

$$
M_{u}=\left(\frac{\overline{u_{\max }-u_{c r}}}{u_{c r}}\right)
$$

The use of both methods allows for range of predicted sediment mobility. However, predictions derived from linear wave theory are generally more conservative compared to the nonlinear theory. Linear wave theory is appropriate when wave steepness is small, and the stream function theory is appropriate for more asymmetric wave in water depths in the range of $0.006 g T^{2}$ to $0.016 g T^{2}$ (McFall et al. 2016).

\subsection{Previous applications of the SMT}

The SMT has already been applied to support USACE dredging and placement operations in the New England District (NAE) (McFall et al. 
2015). In this case, the NAE planned to dredge the entrance channel of Milford Harbor, Connecticut. Two nearby placement sites were proposed for beneficial use (Figure 1-1). One option called for placing the sediment in the nearshore of Gulf Beach in $4 \mathrm{~m}$ of water (blue cross-hatched) while the alternative was to place the sediment in the nearshore of Bayview Beach (red striped) in $3 \mathrm{~m}$ of water. The SMT was used to evaluate which site would have the greatest propensity of sediment mobility for the given sediment characteristics and wave climate, and also compared mobility frequency between normal and storm conditions.

It was found that onshore migration of the material was predicted for both sites, and the frequencies of mobilization were similar under normal wave conditions. Under storm conditions, however, Gulf Beach was predicted to have a greater frequency of mobilization, likely due to the decreased water depth at that site. This result is consistent with the general guidance that nearshore berms should be placed in as little water depth as permissible to function as a feeder berm (McClellan et al. 1990).

Figure 1-1. Proposed nearshore placement sites for dredged sediment near Milford, CT; Gulf Beach (blue hatched area) and Bayview Beach (red striped area). Soundings in feet. National Oceanic and Atmospheric Administration chart 12370.

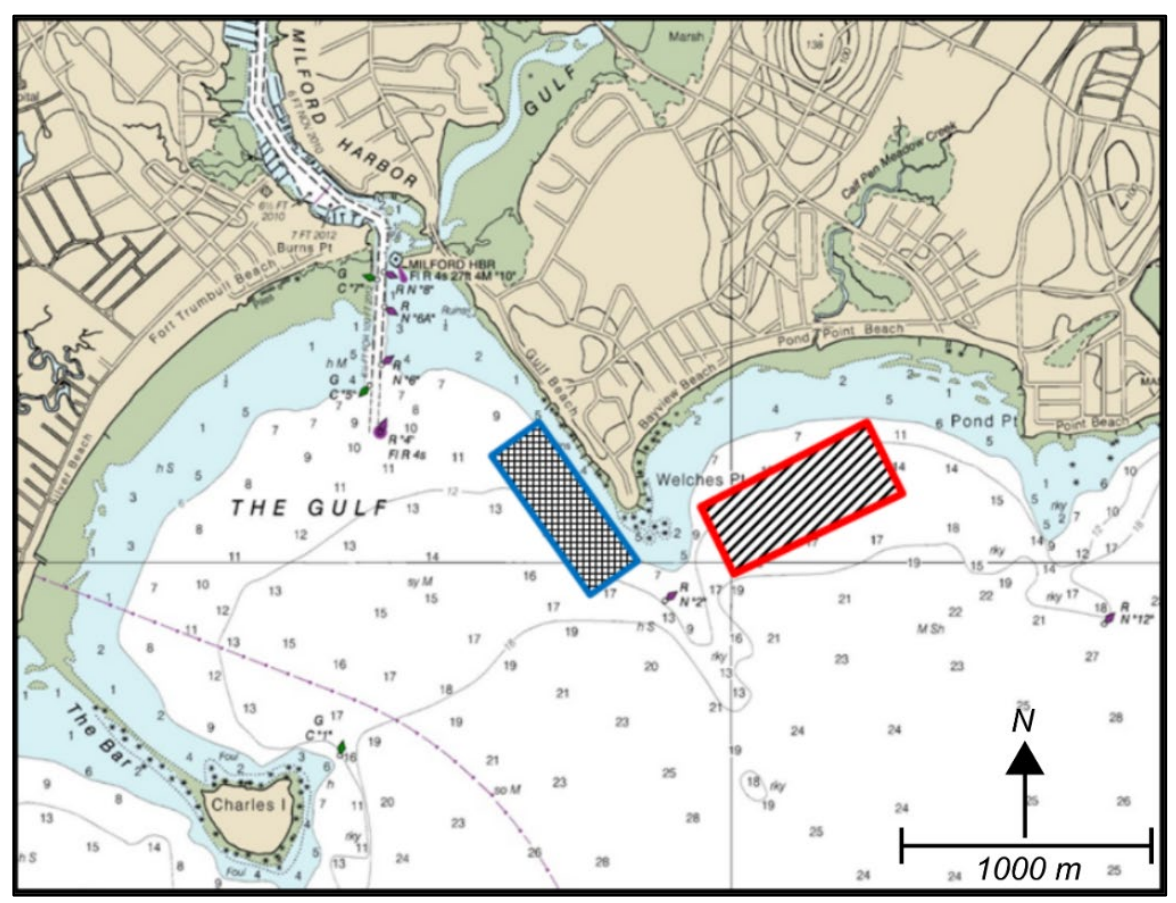

Results derived from the SMT are valid only for cohesionless sediment based on a limited range of grain sizes. Similar to the method of Kraus (1992), the SMT can only predict the likelihood and direction of berm 
movement from the placement site, not the magnitude. Additionally, the SMT does not predict changes in beach width, berm volume, or morphology in time or space. Thus, feedbacks between berm morphology and hydrodynamic stresses are not accounted for beyond the initial condition. Uncertainties in wave height at the placement site should be expected due to uncertainties in the wave transformations from the WIS stations. Finally, bottom current magnitudes in the vicinity are assumed constant and were restricted to either 0.05 or $0.1 \mathrm{~m} / \mathrm{s}$. The effect of additional currents (alongshore, wind-driven, oceanic) should be considered in more robust numerical modeling.

\subsection{Objective}

The initiation of any nearshore placement project would benefit from a reasonable estimate of the likelihood of success from project engineers and planners. Subsequently, the Sediment Mobility Tool (SMT) was developed by McFall et al. (2016) to facilitate and expedite the calculations required for such evaluations.

This Coastal and Hydraulics Laboratory technical report compares results from the SMT against nine previous field studies where nearshore berm behavior was documented. The SMT assesses the likelihood of placed sediment to be mobilized as a function of water depth, wave climate, and grain size. The purpose of this work is to validate the SMT results against well-documented berm placement projects described in the literature.

\subsection{Study approach}

Nine previously studied berms from 1982 to 2009 were selected to qualitatively assess the performance of the SMT. Sites were selected to span a variety of conditions including geography, wave climate, placement depth, and sediment size. Projects from the US Atlantic, Gulf of Mexico, and Pacific seaboards are represented. Since the SMT uses WIS-derived data to characterize the wave field, nearshore berm projects from outside the United States were necessarily excluded. The projects sites used are listed in Table 1-2 along with their primary source of reference.

Table 1-2. Historical nearshore berm placement sites used for SMT comparisons in the present study and their primary references.

\begin{tabular}{|l|c|l|}
\hline Placement Site & Year & Primary References \\
\hline Dam Neck, Virginia & 1982 & Hands and DeLoach (1984) \\
\hline
\end{tabular}




\begin{tabular}{|l|c|l|}
\hline Mobile, Alabama & 1988 & McLellan (1990) \\
\hline Silver Strand, California & 1988 & Andrassay (1991) \\
\hline Port Canaveral, Florida & 1992 & Bodge (1994) \\
\hline Perdido Key, Florida & 1991 & Otay (1994) \\
\hline Newport Beach, California & 1992 & Mesa (1997) \\
\hline Brunswick, Georgia & 2003 & Johnson (2005) \\
\hline Ocean Beach, California & 2005 & Barnard et al. (2006) \\
\hline Fort Meyers, Florida & 2009 & Wang et al. (2013); Brutsché et al. (2014) \\
\hline
\end{tabular}

Required data inputs to run the SMT were derived from the available literature, which included water depth, sediment size, and monitoring period. The dates of the monitoring period were used by the WIS to bracket the hindcasted wave record. Every attempt has been made to faithfully represent the data, referring to the original source when possible (Table 1-2). On occasion, it was necessary to derive information from outside the original source where it was part of a compiled list or literature review. If a range of data was provided - for example, water depth - then the average was used. Regarding monitoring dates, in some cases only generalized information was provided (e.g., "May 1990 - May 1992"); exact dates are preferred in order to best match WIS-derived wave data to the monitoring period. For these situations, dates were selected as the first day of each month between the reported monitoring periods (e.g., 1 May 1990 - 1 May 1992).

Finally, the SMT was run for each location, and a qualitative comparison was then made between the results of the SMT to observed berm migration trends reported in the literature. 


\section{Results}

Results are presented in chronological order. First, a brief summary is provided for each location describing the project site, overview of berm construction, hydrographic description, and general observations on berm movement for the monitoring period. The SMT results follow with written explanation and interpretation.

For each site, a table is first provided to summarize information regarding berm construction, information used to run the SMT, and the sediment mobility direction for the specified size class. The output from the SMT follows. The SMT reports the distribution of bed shear stresses and nearbed orbital velocities calculated from the wave record of the nearest WIS station for the monitoring duration of the berm. These results are presented as histographs, one for bed shear stress and one for nearbottom velocities, for each site. The vertical lines in the graphs represent the critical threshold criteria for movement of the specified grain diameter. Wave rose diagrams are not provided as part of the results, though the resulting wave vector directions are reported in the summary tables.

\subsection{Site 1: Dam Neck, Virginia (1982)}

\subsubsection{Site description and berm construction}

In 1982, 650,000 $\mathrm{m}^{3}$ of dredged material from nearby ship channels was placed within the Dam Neck Disposal Area approximately 4-5 kilometers $(\mathrm{km})$ offshore of Virginia Beach. The disposal area (Figure 2-1) had already received more than 15 million $\mathrm{m}^{3}$ of dredged material since 1967 , but the material was always placed in a dispersive way that created a lowrelief ridge. In contrast, the intent of the 1982 placement was to build a mound of considerable relief within the disposal area to determine future placement protocols and predict mound stability.

A single mound, $3.3 \mathrm{~m}$ in relief, consisting of silt and very fine sand, was constructed in 10-11 m of water depth. DeLoach (1985) reported the base of the mound was approximately 100 acres (40 hectares), which translates to a diameter of approximately 72 meters.

Approximately $40 \%$ of sediment dredged from the Thimble Shoal Channel (and 8\% from the Cape Henry Channel) was reported as finer than 
75 microns. The mean particle diameter of the dredged sediment, as reported by DeLoach (1985), was less than 0.2 millimeter (mm) with no other specifics provided. However, compiled data from Arhens and Hands (1998; their Table 1) reported a median size of $0.08 \mathrm{~mm}$ and thus selected for use in the SMT. The surrounding native material was noted to be coarser with megaripples superimposed. Side slopes of the mound averaged 1:130.

Figure 2-1. Location map of placement site Dam Neck, Virginia. Image date 2016.

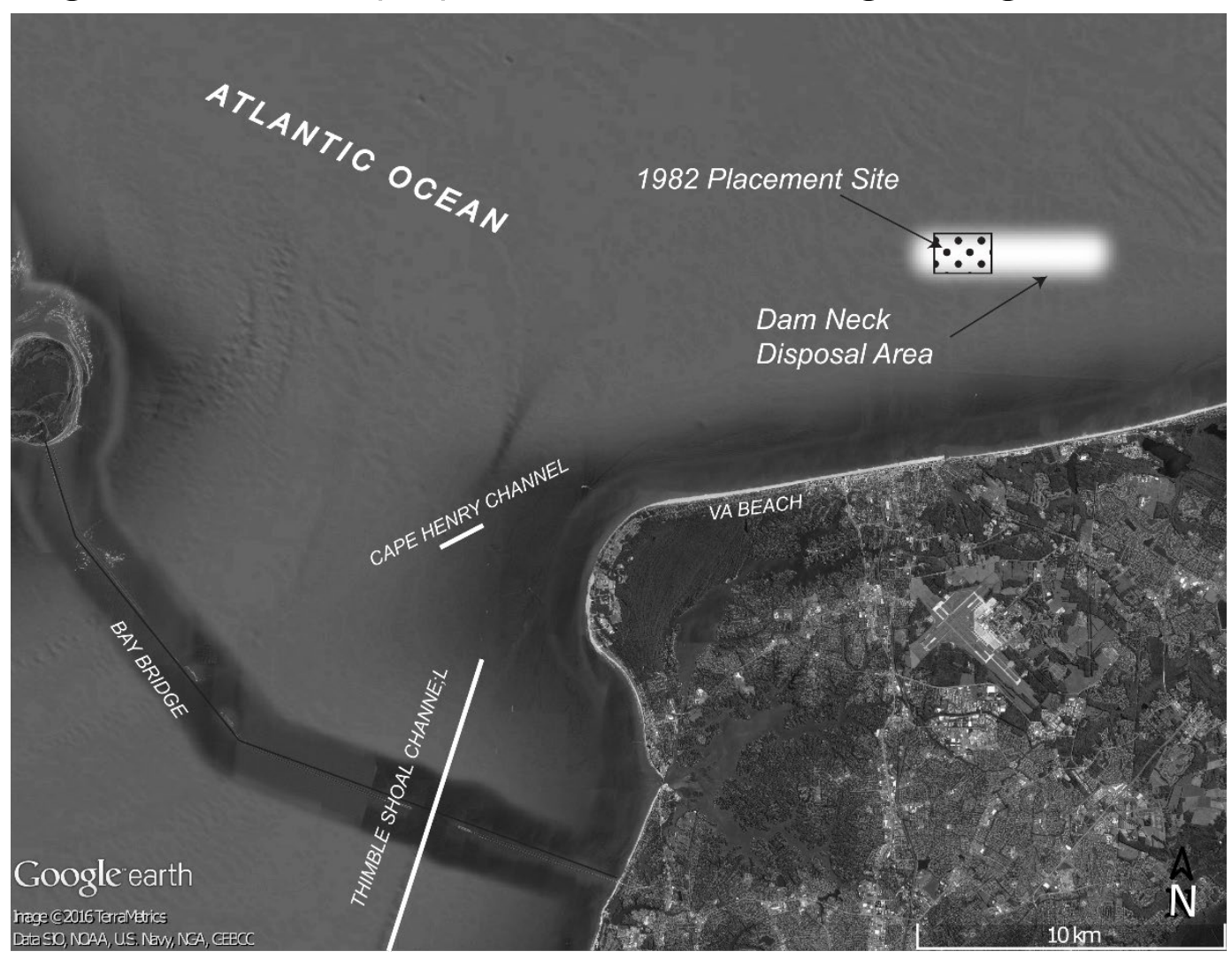

\subsubsection{Hydrographic description}

Direct measurement of the wave climate was not reported in the available literature. Hindcast data (16 km offshore) for 1983 indicate a mean significant wave height of $1.1 \mathrm{~m}$ and 9-second (s) mean wave period (Table 2-1). The most frequent wave direction during the monitoring period was from the east-southeast; although, on the basis of megaripple orientation, Hands and DeLoach (1984) suggested a prevailing wave direction from the northeast within the vicinity of the disposal area. As reported by DeLoach (1985), deepwater significant wave heights of 2.7-3.0 $\mathrm{m}$ and $7 \mathrm{~s}$ periods were derived from forecasting curves. 


\subsubsection{Monitoring and berm evolution}

Ahrens and Hands (1998) suggested that this mound was placed in a transition zone. Reported observations through repeat surveys indicated that while the position of the mound was relatively stable, the crest (depth less than $8 \mathrm{~m}$ ) was considered somewhat active, evidenced by $60 \mathrm{~cm}$ of deflation over a 15-month period. Active reworking of the upper $30 \mathrm{~cm}$ was inferred by the lack of stratigraphy observed from sediment cores.

Sediment from the crest appeared to move landward, though only through the passing of storm waves (DeLoach 1985). No significant gains or losses were detected around the perimeter of the mound where depths were greater $(8.1-10.4 \mathrm{~m})$. Thus, it was speculated that placing the mound at a depth shallower than $8 \mathrm{~m}$ would have resulted in an active feeder deposit.

Table 2-1. Summary characteristics table for Dam Neck, Virginia.

\begin{tabular}{|c|c|c|c|c|c|c|c|c|}
\hline \multicolumn{3}{|c|}{ Monitoring Dates } & \multicolumn{2}{|c|}{$\begin{array}{c}3 / 2 / 87- \\
1 / 8 / 88\end{array}$} & & & & \\
\hline \multicolumn{3}{|c|}{$\begin{array}{l}\text { Placement Volume } \\
\qquad\left(\mathrm{m}^{3}\right)\end{array}$} & \multicolumn{2}{|c|}{$\begin{array}{l}\text { Berm } \\
\text { Dimensions } \\
\text { (m) (length } \mathrm{x} \\
\text { width) }\end{array}$} & $\begin{array}{l}\text { Water } \\
\text { Depth } \\
\text { (m) }\end{array}$ & $\begin{array}{l}\text { Berm } \\
\text { Relief } \\
(\mathrm{m})\end{array}$ & $\begin{array}{c}\text { Mean } \\
\text { Sand } \\
\text { Size } \\
(\mathrm{mm})\end{array}$ & $\begin{array}{l}\text { Observed } \\
\text { Berm } \\
\text { Migration }\end{array}$ \\
\hline \multicolumn{3}{|c|}{650,000} & & $\mathrm{n} / \mathrm{a}$ & 10.5 & 3.3 & 0.08 & Stable \\
\hline \multicolumn{9}{|c|}{ SMT Parameters } \\
\hline $\begin{array}{l}\text { WIS } \\
\text { Station }\end{array}$ & $\begin{array}{l}\text { WIS } \\
\text { Depth } \\
\text { (m) }\end{array}$ & \multicolumn{2}{|c|}{$\begin{array}{c}\text { Shoreline } \\
\text { Angle }\end{array}$} & $\begin{array}{c}\text { Assumed } \\
\text { Longshore } \\
\text { Current } \\
(\mathrm{m} / \mathrm{s})\end{array}$ & $\begin{array}{c}\text { Average } \\
\text { Wave } \\
\text { Height } \\
\text { (m) }\end{array}$ & $\begin{array}{l}\text { Average } \\
\text { Wave } \\
\text { Period } \\
\text { (s) }\end{array}$ & $\begin{array}{l}\text { Wave } \\
\text { Vector } \\
\text { (deg) }\end{array}$ & $\begin{array}{l}\text { Average Wind } \\
\text { Direction (deg) }\end{array}$ \\
\hline 63199 & 19 & \multicolumn{2}{|c|}{166} & 0.05 & 1.1 & 9 & 94 & 138 \\
\hline
\end{tabular}

\subsubsection{SMT results}

Results from the SMT show a high frequency of sediment mobility, especially for the finer grain sizes represented at the mound (Figure 2-3). The frequency of mobility is approximately $80 \%$ using the linear wave theory threshold criteria with a median grain size of $0.08 \mathrm{~mm}$; however, sediment mobility was predicted in the offshore direction for grain sizes less than $0.1 \mathrm{~mm}$ (Table 2-2). DeLoach (1985) reported that the only movement was that of lateral spreading and loss of material from the mound's crest. Longshore-dominated sediment transport is expected based on the near-shore parallel wave resultant vector at the nearshore site. 
Another possible explanation for the lack of cross-shore transport could be related to the mound geometry. Berm construction guidance found in the literature (Zwamborn et al. [1970]; McLellan [1990]) recommend linear berms as opposed to mounds to prevent wave focusing. Therefore, there is some speculation that wave refraction around the mound may have caused dynamic feedbacks between morphology and hydrodynamics that prevented substantial shore-directed sediment transport.

Figure 2-3. Distribution of maximum bed shear stress (top) and near-bottom velocities (bottom) for site Dam Neck, Virginia (WIS station 63199). $N$ is the number of hourly wave heights in each bin during the monitoring period.

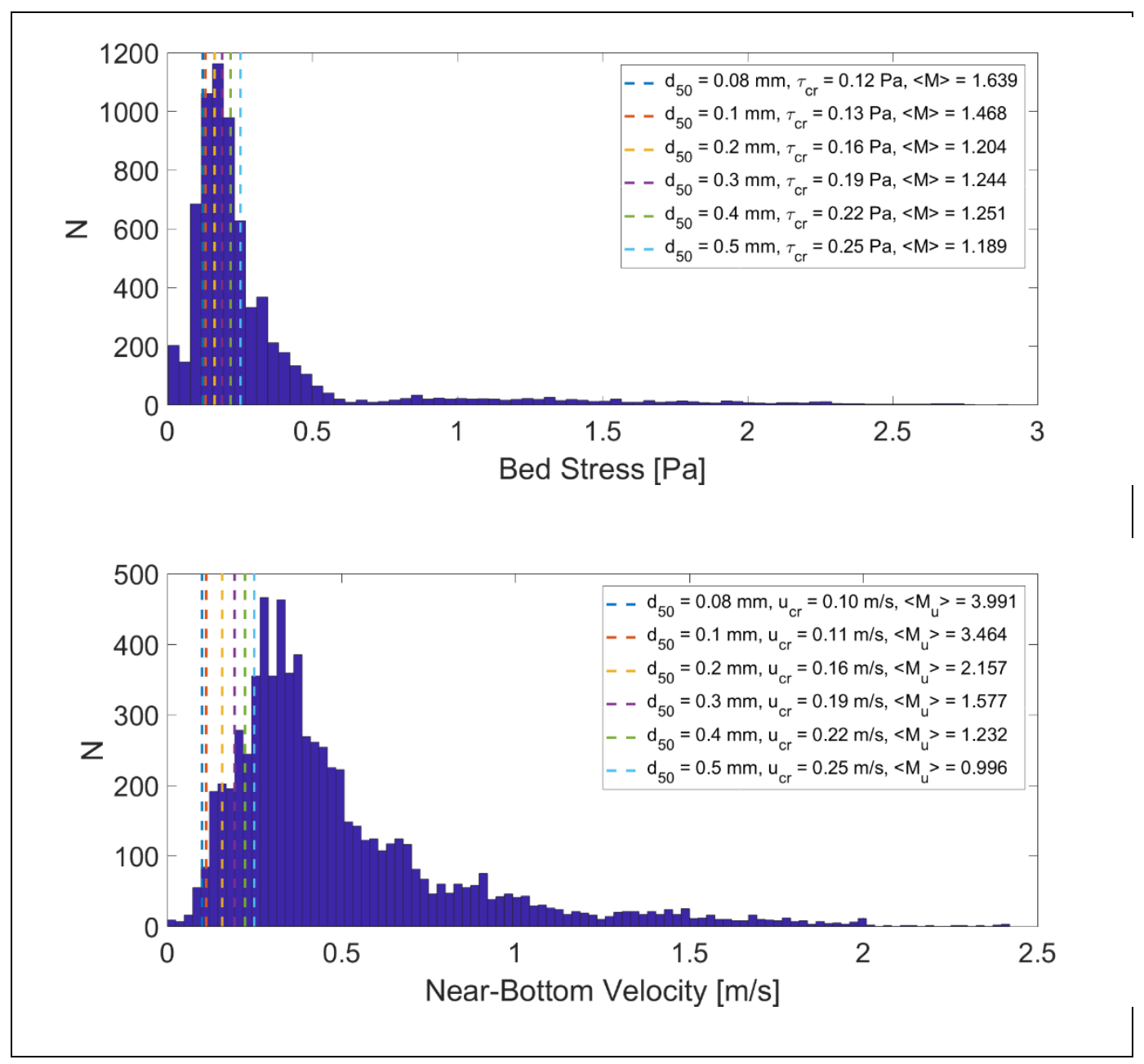


Table 2-2. Dam Neck, Virginia, frequency of mobilization and predicted sediment migration for indicated grain sizes. Median grain size of placed material in bold.

\begin{tabular}{|c|c|c|c|}
\hline $\begin{array}{c}\mathbf{d}_{50} \\
(\mathrm{~mm})\end{array}$ & $\begin{array}{c}\text { Bed Shear Stress } \\
\text { Mobilization }\left(\mathbf{F}_{\mathbf{M}}\right)\end{array}$ & $\begin{array}{c}\text { Near-Bottom Velocity } \\
\text { Frequency of Mobilization } \\
\left(\mathbf{F}_{\mathbf{M u}}\right)\end{array}$ & $\begin{array}{c}\text { Predicted Sediment } \\
\text { Migration }\end{array}$ \\
\hline 0.08 & $84 \%$ & $99 \%$ & $88 \%$ Offshore \\
\hline 0.1 & $80 \%$ & $98 \%$ & $70 \%$ Offshore \\
\hline 0.2 & $66 \%$ & $94 \%$ & $100 \%$ Onshore \\
\hline 0.3 & $65 \%$ & $90 \%$ & $100 \%$ Onshore \\
\hline 0.4 & $66 \%$ & $85 \%$ & $100 \%$ Onshore \\
\hline 0.5 & $64 \%$ & $81 \%$ & $100 \%$ Onshore \\
\hline
\end{tabular}

\subsection{Site 2: Mobile Outer Mound (MOM), Alabama (1988)}

\subsubsection{Site description and berm construction}

The MOM (sometimes referred to as Mobile North in the literature) was constructed with the intent of being a stable mound to provide potential fish habitat and to dissipate wave energy. Located $8 \mathrm{~km}$ south of Dauphin Island, Alabama, it is the largest of a series of three berms constructed in the area (Figure 2-4). Approximately 14.3 million $\mathrm{m}^{3}$ of dredged sediment were used to create the berm in a designated disposal area approximately $450 \mathrm{~m} \times 300 \mathrm{~m}$. Placement depths ranged from $10.6 \mathrm{~m}$ to $13.7 \mathrm{~m}$ at the toe of the large ebb-tidal delta fronting the inlet. Sediments were dredged from two locations, 10 million $\mathrm{m}^{3}$ from Mobile Bay and 4.3 million m3 from the bar channel at the entrance of the bay. Sediments within the test area were heterogeneous, as the bay sediments were mostly clay-rich mud of high plasticity, while the bar channel sediments were comprised of silty and clayey sands (McLellan and Imsand 1989). Based on 100 surface grab samples, Hands et al. (1992) reported a median diameter of $0.067 \mathrm{~mm}$. 
Figure 2-4. Location map of the MOM, Alabama (after Hands et al. [1992]). Image date 2016.

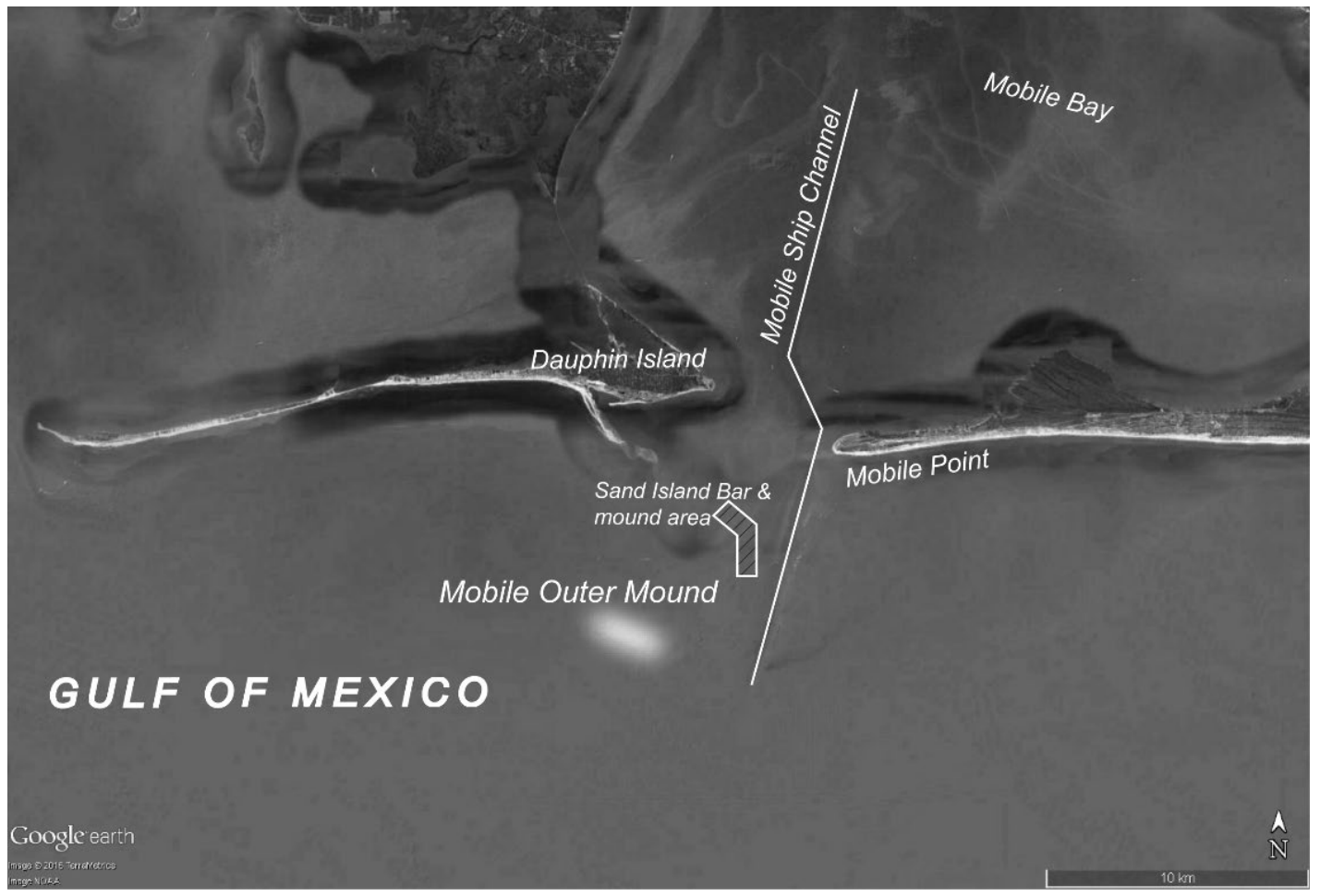

\subsubsection{Hydrographic description}

Tides are diurnal with a $37 \mathrm{~cm}$ range (Jones and Patterson 2006). McAneny (1986), as cited in McClelland and Ismand (1989), reported average wave heights of $1.0 \mathrm{~m}$ with $5 \mathrm{~s}$ periods typically approaching from the southeast. Hydrodynamic data reported in McGehee et al. (1994) showed that typical wave conditions in the area range from calm to steep wind waves up to $3 \mathrm{~m}$ in height with $4 \mathrm{~s}$ to $9 \mathrm{~s}$ wave periods and storm swell with $10 \mathrm{~s}$ to $12 \mathrm{~s}$ periods. Wave direction is typically from the south during normal weather and from the north during passing frontal systems; more than 40 tropical storms have impacted the area since 1969.

The normal range of current velocities are highly variable and range between 0.05 to $0.40 \mathrm{~m} / \mathrm{s}$, though storm surges can produce velocities exceeding $1 \mathrm{~m} / \mathrm{s}$ (McLellan and Imsand 1989). Close to the placement sites, measured near-bottom currents on the order of $0.3 \mathrm{~m} / \mathrm{s}$ to the eastsoutheast were common, while maximum storm-wave velocities were measured up to $1 \mathrm{~m} / \mathrm{s}$ (McGehee et al. 1994). Near the barriers, longshore drift is generally westward (Jones and Patterson 2006). 


\subsubsection{Monitoring and berm evolution}

Limited monitoring of the MOM showed that it was stable through a few years after placement and was expected to remain stable for many years later due to its large mass (Hands et al. 1992). This in contrast to the Sand Island Berm and Sand Island Mound (Table 2-3) both of which were reported to steadily migrate shoreward over the initial 3-year period.

Table 2-3. Summary characteristics table for Mobile Outer Mound, Alabama.

\begin{tabular}{|c|c|c|c|c|c|c|c|c|}
\hline \multirow{2}{*}{$\begin{array}{c}\begin{array}{c}\text { Monitoring } \\
\text { Dates }\end{array} \\
\begin{array}{c}\text { Placement } \\
\text { Volume } x \\
10^{6}\left(\mathrm{~m}^{3}\right)\end{array}\end{array}$} & \multicolumn{2}{|c|}{$\begin{array}{c}3 / 2 / 87- \\
1 / 8 / 88\end{array}$} & & & & & & \\
\hline & \multicolumn{2}{|c|}{$\begin{array}{c}\text { Berm } \\
\text { Dimensions }(\mathrm{m}) \\
\text { (length } \mathrm{x} \text { width) }\end{array}$} & $\begin{array}{l}\text { Water } \\
\text { Depth } \\
(\mathrm{m})\end{array}$ & \multicolumn{2}{|c|}{$\begin{array}{l}\text { Berm } \\
\text { Relief } \\
\text { (m) }\end{array}$} & \multicolumn{2}{|c|}{$\begin{array}{l}\text { Mean } \\
\text { Sand } \\
\text { Size } \\
(\mathrm{mm})\end{array}$} & $\begin{array}{l}\text { Observed } \\
\text { Berm } \\
\text { Migration }\end{array}$ \\
\hline 14.3 & \multicolumn{2}{|c|}{$4,500 \times 200$} & $\begin{array}{l}10.6- \\
13.7\end{array}$ & \multicolumn{2}{|c|}{6.6} & \multicolumn{2}{|c|}{0.25} & Stable \\
\hline \multicolumn{9}{|c|}{ SMT Input Parameters } \\
\hline $\begin{array}{c}\text { WIS } \\
\text { Station }\end{array}$ & $\begin{array}{l}\text { WIS } \\
\text { Depth } \\
\text { (m) }\end{array}$ & $\begin{array}{c}\text { Shoreline } \\
\text { Angle }\end{array}$ & $\begin{array}{c}\text { Assumed } \\
\text { Longshore } \\
\text { Current } \\
(\mathrm{m} / \mathrm{s})\end{array}$ & $\begin{array}{c}\text { Average } \\
\text { Wave } \\
\text { Height } \\
\text { (m) }\end{array}$ & & $\begin{array}{l}\text { age } \\
\text { ive } \\
\text { d (s) }\end{array}$ & $\begin{array}{l}\text { Wave } \\
\text { Vector } \\
\text { (deg) }\end{array}$ & $\begin{array}{l}\text { Average } \\
\text { Wind } \\
\text { Direction } \\
\text { (deg) }\end{array}$ \\
\hline 73153 & 12 & 275 & 0.05 & 0.57 & & 6 & 151 & 138 \\
\hline
\end{tabular}

\subsubsection{SMT results}

The SMT predicted that the MOM would be stable, as indicated by the low frequency of mobility (8\%-26\%) and negative mobility values (Figure 2-5). The negative mean mobility scores indicate that the maximum calculated shear stresses and bottom velocities were, on average, less than the critical stress required for sediment transport. The more conservative bed stress method estimates that only $10 \%$ of the waves would have exceeded the critical threshold for movement ( $f_{M}=8 \%$ for $d_{50}=0.25 \mathrm{~mm}$ ), whereas the average maximum bed shear stress is nearly $70 \%$ less than the critical stress as indicated by the mean mobility score $(M=-0.69)$. Likewise, the nearbottom velocity method also predicts that a very low percentage of waves $\left(f_{M u}=17 \%\right)$ were capable of moving sediment in the mean size class. These results differ little for smaller size classes (Table 2-4). Thus, the deep-water placement of this mound prevented any significant movement, although Otay (1994) reported that wave reduction in the lee of the mound was approximately $30 \%$ during normal seas and $75 \%$ during extreme seas. The MOM was intended to be constructed as a stable feature, and the SMT 
would have predicted the same for the given depth and grain size. However, note that silt and clay may have comprised a significant fraction of the total sediment composition (perhaps 10\%) and the SMT was not designed to predict the mobility of cohesive sand-clay mixtures.

Figure 2-5. Distribution of maximum bed shear stress (top) and near-bottom velocities (bottom) for site MOM, Alabama (WIS station 73153). Nis the number of hourly wave heights in each bin during the monitoring period.

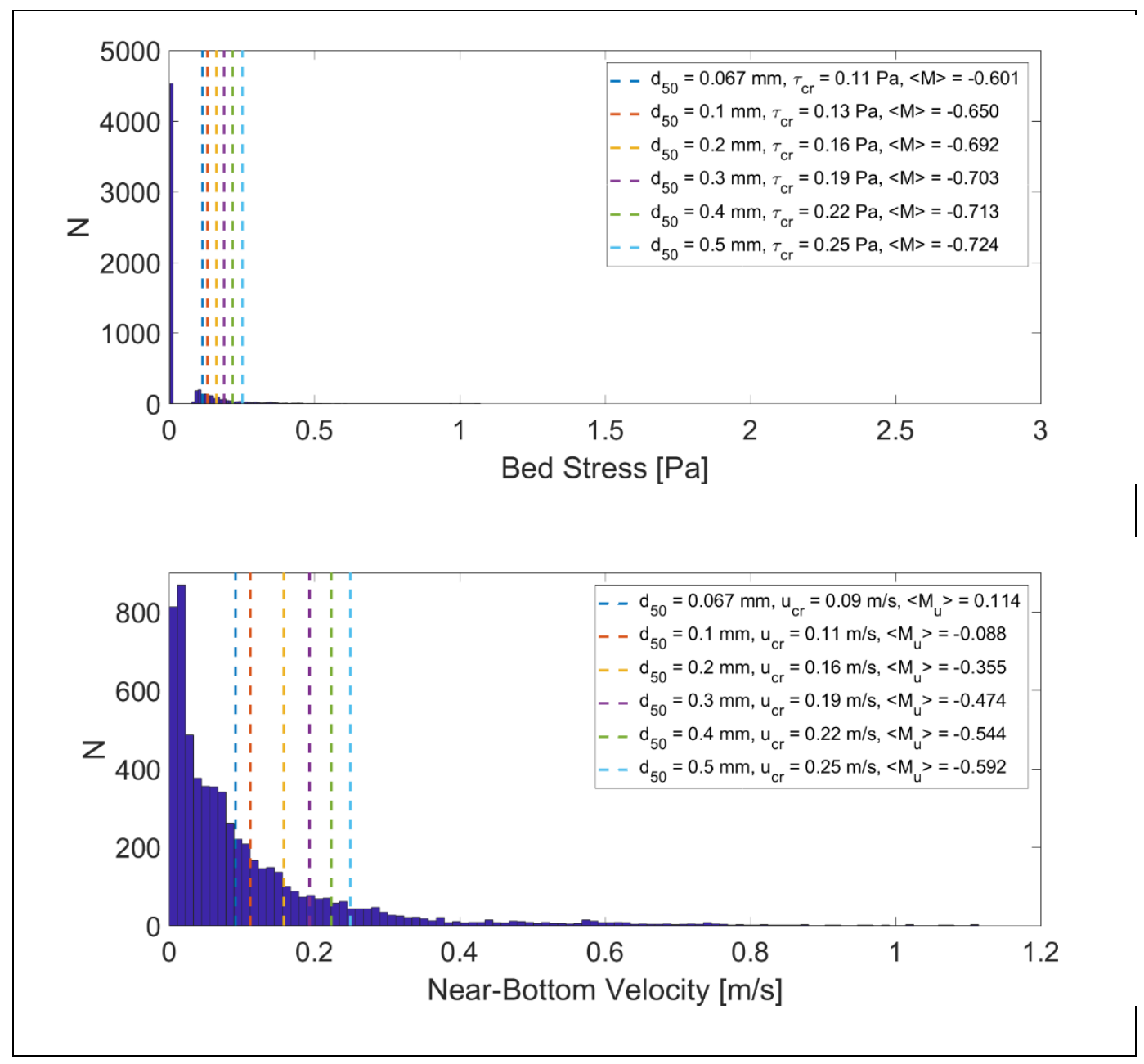


Table 2-4. MOM frequency of mobilization and predicted sediment migration for indicated grain sizes. Median grain size of placed material in bold.

\begin{tabular}{|c|c|c|c|}
\hline $\begin{array}{c}\text { d50 } \\
(\mathbf{m m})\end{array}$ & $\begin{array}{c}\text { Fed Shear Stress } \\
\text { Mobilization }\left(\boldsymbol{F}_{\boldsymbol{M}}\right)\end{array}$ & $\begin{array}{c}\text { Near-Bottom Velocity } \\
\text { Mobilization }\left(\boldsymbol{F}_{\boldsymbol{M} \boldsymbol{u}}\right)\end{array}$ & $\begin{array}{c}\text { Predicted Sediment } \\
\text { Migration }\end{array}$ \\
\hline 0.1 & $15 \%$ & $29 \%$ & $65 \%$ Onshore \\
\hline 0.2 & $10 \%$ & $19 \%$ & $98 \%$ Onshore \\
\hline 0.25 & $8 \%$ & $17 \%$ & $100 \%$ Onshore \\
\hline 0.3 & $8 \%$ & $15 \%$ & $100 \%$ Onshore \\
\hline 0.4 & $8 \%$ & $12 \%$ & $100 \%$ Onshore \\
\hline 0.5 & $8 \%$ & $9 \%$ & $100 \%$ Onshore \\
\hline
\end{tabular}

\subsection{Site 3: Silver Strand, California (1988)}

\subsubsection{Site description and berm construction}

The Silver Strand berm is one of many nourishment projects that have been completed along this shoreline since the 1940 os to mitigate beach erosion (Patsch and Griggs 2007). This highly altered $26 \mathrm{~km}$ stretch of beach is part of the Silver Strand littoral zone with northerly longshore sediment transport estimated at $138,000 \mathrm{~m}^{3}$ per year. In December of 1988, approximately 113,000 $\mathrm{m}^{3}$ of material dredged from the entrance channel of San Diego Bay was placed 240 m offshore of Silver Strand State Park, 6 miles south of the entrance to San Diego Bay (Figure 2-6). The berm measured $360 \times 180 \mathrm{~m}$ and was constructed in water depths between 4.8 and $8.5 \mathrm{~m}$ with a relief of approximately $2.1 \mathrm{~m}$. The dredged material consisted mostly of medium sand $\left(d_{50}=0.18 \mathrm{~mm}\right)$ with $12 \%$ silt and clay while the native material was slightly larger with less silt and clay $\left(d_{50}=0.25 ; 6 \%\right.$ silt and clay) (Juhnke 1990). 
Figure 2-6. Location map of Silver Strand placement site, California. Image date 2018.

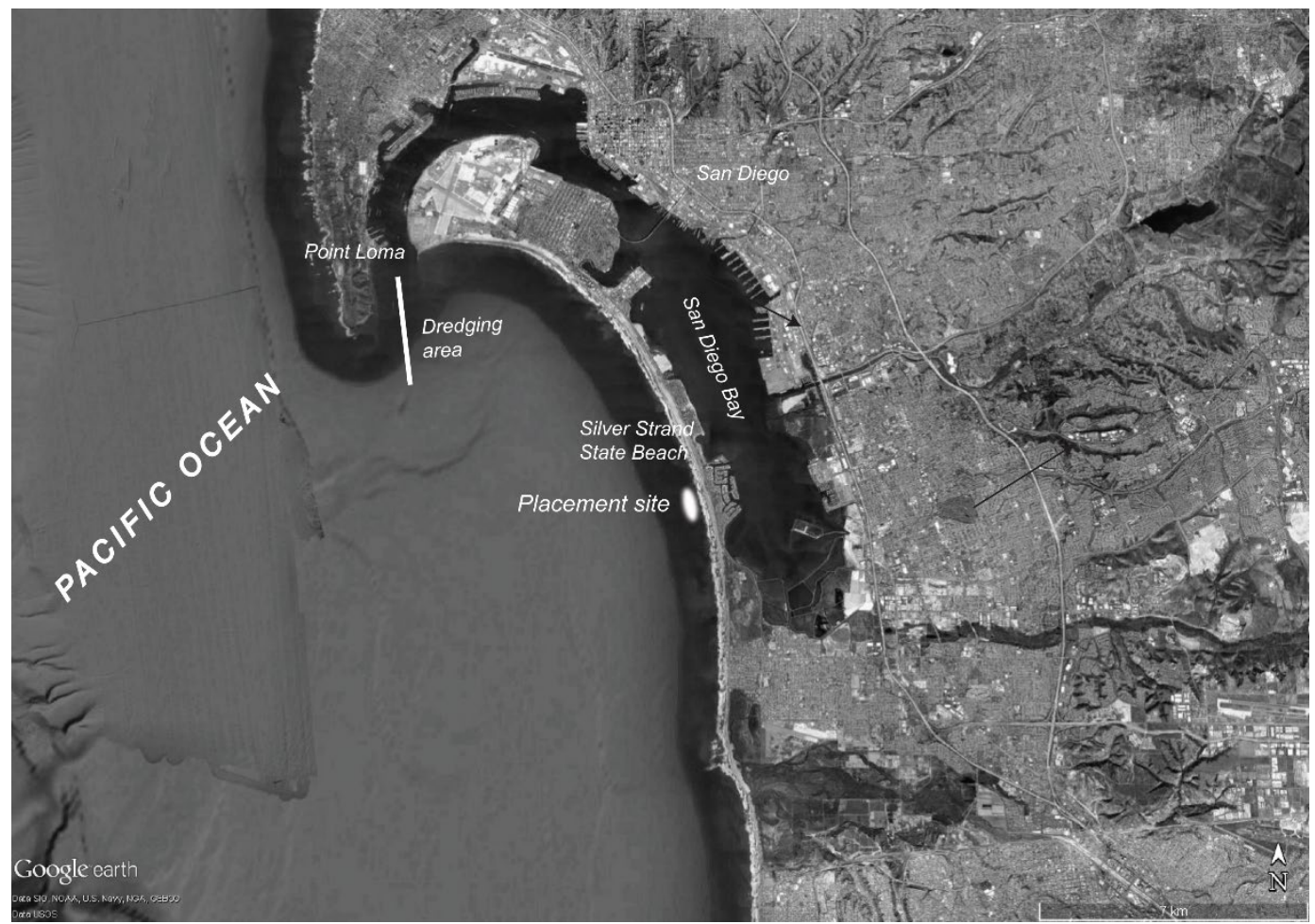

\subsubsection{Hydrographic description}

The dominant wave energy originates from swell waves (6-10 s periods) approaching from the northwest; the Silver Strand shoreline is mostly sheltered from these waves by Point Loma (Inman 1976, as reported in Patsch and Griggs 2007). Analysis of wave data from the nearest WIS station (83107) reveals that waves approach most frequently from the west with an average significant wave height of $1 \mathrm{~m}$ and average wave period of $13 \mathrm{~s}$ (Table 2-5). Over the monitoring period, 114 days of wave gauge data from near the berm showed that wave heights were typically between 0.5 and $0.75 \mathrm{~m}$ with average periods between 7 and $9 \mathrm{~s}$; wave heights exceeding 1.0 m occurred only $10 \%$ of the time (Andrassay 1991).

\subsubsection{Monitoring and berm evolution}

Seven cross-shore survey lines were established to track the mound's evolution over a period of nearly 2 years. Based on the survey data, the berm migrated shoreward and contributed to accretion by reducing wave energy in the lee of the berm causing deposition of longshore drift sediments. 
A survey approximately 70 days post placement showed that the crest of the berm moved shoreward by an average of $34 \mathrm{~m}$ and the shoreline widened by an average of $40 \mathrm{~m}$ over this same time period; the total volume was conserved. Tracking of the crest position beyond that date was not possible due to berm deflation. Subsequent monitoring showed that the total sediment volume increased during summer months, remained unchanged during the fall, and lost volume during winter months. Seasonal changes compared to the periphery of the berm could not be determined since profiles were not taken outside the bounds of the placement area. Two years after placement, it was estimated that $62 \%$ of the original placement volume remained.

Table 2-5. Summary characteristics table for Silver Strand, California.

\begin{tabular}{|c|c|c|c|c|c|c|c|c|}
\hline $\begin{array}{c}\text { Monitoring } \\
\text { dates }\end{array}$ & \multicolumn{2}{|c|}{$\begin{array}{c}12 / 8 / 88- \\
11 / 1 / 90\end{array}$} & & & & & & \\
\hline $\begin{array}{l}\text { Placement } \\
\text { Volume } \\
\left(\mathrm{m}^{3}\right)\end{array}$ & \multicolumn{2}{|c|}{$\begin{array}{c}\text { Berm } \\
\text { Dimensions (m) } \\
(\mathrm{I} \times \mathrm{w})\end{array}$} & $\begin{array}{c}\text { Water } \\
\text { Depth }(\mathrm{m})\end{array}$ & \multicolumn{2}{|c|}{$\begin{array}{l}\text { Berm } \\
\text { Relief } \\
(\mathrm{m})\end{array}$} & \multicolumn{2}{|c|}{$\begin{array}{l}\text { Mean } \\
\text { Sand } \\
\text { Size } \\
(\mathrm{mm})\end{array}$} & $\begin{array}{l}\text { Observed } \\
\text { Berm } \\
\text { Migration }\end{array}$ \\
\hline 113,000 & \multicolumn{2}{|c|}{$360 \times 180$} & $4.6-5.5$ & \multicolumn{2}{|c|}{2.1} & \multicolumn{2}{|c|}{0.25} & Onshore \\
\hline \multicolumn{9}{|c|}{ SMT Input Parameters } \\
\hline $\begin{array}{l}\text { WIS } \\
\text { Station }\end{array}$ & $\begin{array}{l}\text { WIS } \\
\text { Depth } \\
\text { (m) }\end{array}$ & $\begin{array}{c}\text { Shoreline } \\
\text { Angle }\end{array}$ & $\begin{array}{l}\text { Assumed } \\
\text { Longshore } \\
\text { Current } \\
(\mathrm{m} / \mathrm{s})\end{array}$ & $\begin{array}{l}\text { Average } \\
\text { Wave } \\
\text { Height } \\
\text { (m) }\end{array}$ & & & $\begin{array}{c}\text { Wave } \\
\text { Vector } \\
\text { (deg) }\end{array}$ & $\begin{array}{l}\text { Average } \\
\text { Wind } \\
\text { Direction } \\
\text { (deg) }\end{array}$ \\
\hline 83107 & 848 & 342 & 0.1 & 1.0 & & & 271 & 289 \\
\hline
\end{tabular}

\subsubsection{SMT results}

Results from the SMT (Figure 2-7) show that the Silver Strand site should be ideal for berm placement. The distribution of maximum bed shear stresses and near-bottom velocities show that sediment would be mobilized $99 \%$ of the time for all grain sizes. Finer sediments on the order of $0.1 \mathrm{~mm}$ are predicted to be mobilized frequently $\left(f_{M}=99.4 \%\right)$, but only $62 \%$ of that sediment is predicted to move in the onshore direction (Table 2-6), thus some loss of fines would be expected to occur. For coarser sediment, however, as represented at the placement site $\left(d_{50}=\right.$ $0.25 \mathrm{~mm}$ ), $100 \%$ of the waves were predicted to move sediment in the onshore direction. 
Figure 2-7. Distribution of maximum bed shear stress (top) and near-bottom velocities (bottom) for site Silver Strand, California (WIS station 83107). Nis the number of hourly wave heights in each bin during the monitoring period.

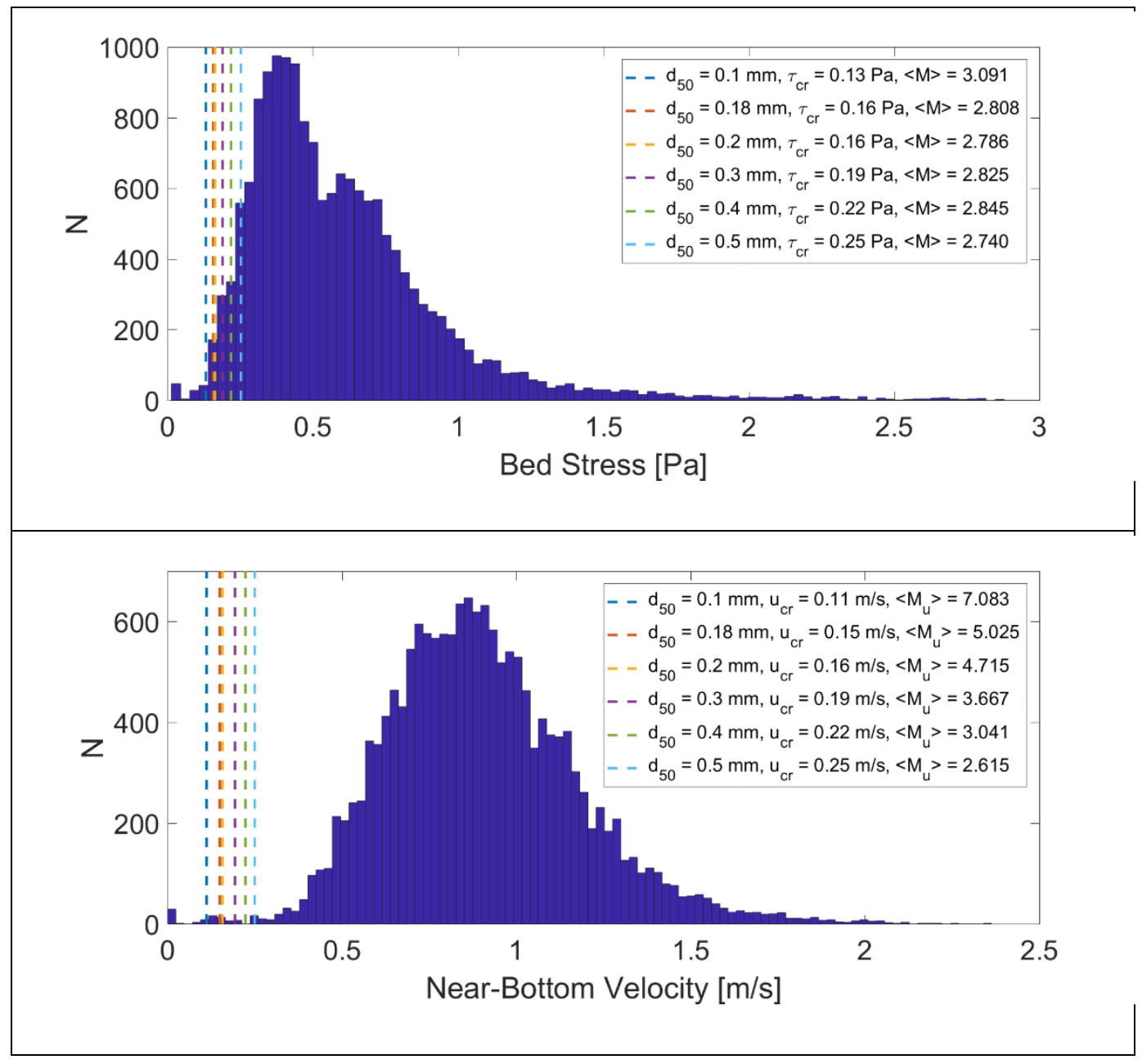

Table 2-6. Silver Strand frequency of mobilization and predicted sediment migration for indicated grain sizes. Median grain size of placed material in bold.

\begin{tabular}{|c|c|c|c|}
\hline $\begin{array}{c}\text { d50 } \\
(\mathbf{m m})\end{array}$ & $\begin{array}{c}\text { Bed Shear Stress } \\
\text { Mobilization }\left(\boldsymbol{F}_{\boldsymbol{M}}\right)\end{array}$ & $\begin{array}{c}\text { Near-Bottom Velocity } \\
\text { Mobilization }\left(\boldsymbol{F}_{\boldsymbol{M} \boldsymbol{u}}\right)\end{array}$ & $\begin{array}{c}\text { Predicted Sediment } \\
\text { Migration }\end{array}$ \\
\hline 0.1 & $99 \%$ & $100 \%$ & $62 \%$ Onshore \\
\hline 0.2 & $100 \%$ & $100 \%$ & $98 \%$ Onshore \\
\hline 0.25 & $100 \%$ & $100 \%$ & $100 \%$ Onshore \\
\hline 0.3 & $100 \%$ & $100 \%$ & $100 \%$ Onshore \\
\hline 0.4 & $100 \%$ & $100 \%$ & $100 \%$ Onshore \\
\hline 0.5 & $100 \%$ & $100 \%$ & $100 \%$ Onshore \\
\hline
\end{tabular}




\subsection{Site 4: Port Canaveral, Florida (1992)}

\subsubsection{Site description and berm construction}

The Port Canaveral berm was part of an ongoing effort to mitigate the down-drift erosive effects after construction of the Port Canaveral Harbor and jetty in the 1950s (Bodge, 1994). Multiple sand bypassing and nourishment projects have been completed to this effect ever since. In July of 1992, 121,000 $\mathrm{m}^{3}$ of dredge material from the Port Canaveral entrance channel was used to construct a berm 6 miles south of the jetty just offshore of Cocoa Beach, Florida (Figure 2-8). The berm was placed between the $5.5 \mathrm{~m}$ and $7 \mathrm{~m}$ depth contours (relative to mean low water [MLW]) and had a typical berm relief of approximately $1.6 \mathrm{~m}$. The shoreward side slopes were between 1:24 and 1:54 while seaward slopes varied between 1:12 and 1:35. Native sediments had a median diameter of $0.104 \mathrm{~mm}$ with $10 \%$ fines, on average, while berm sediments had a median diameter of $0.4 \mathrm{~mm}$ and $3 \%$ fines.

Figure 2-8. Location map of Port Canaveral placement site, Florida. Image date 2016.

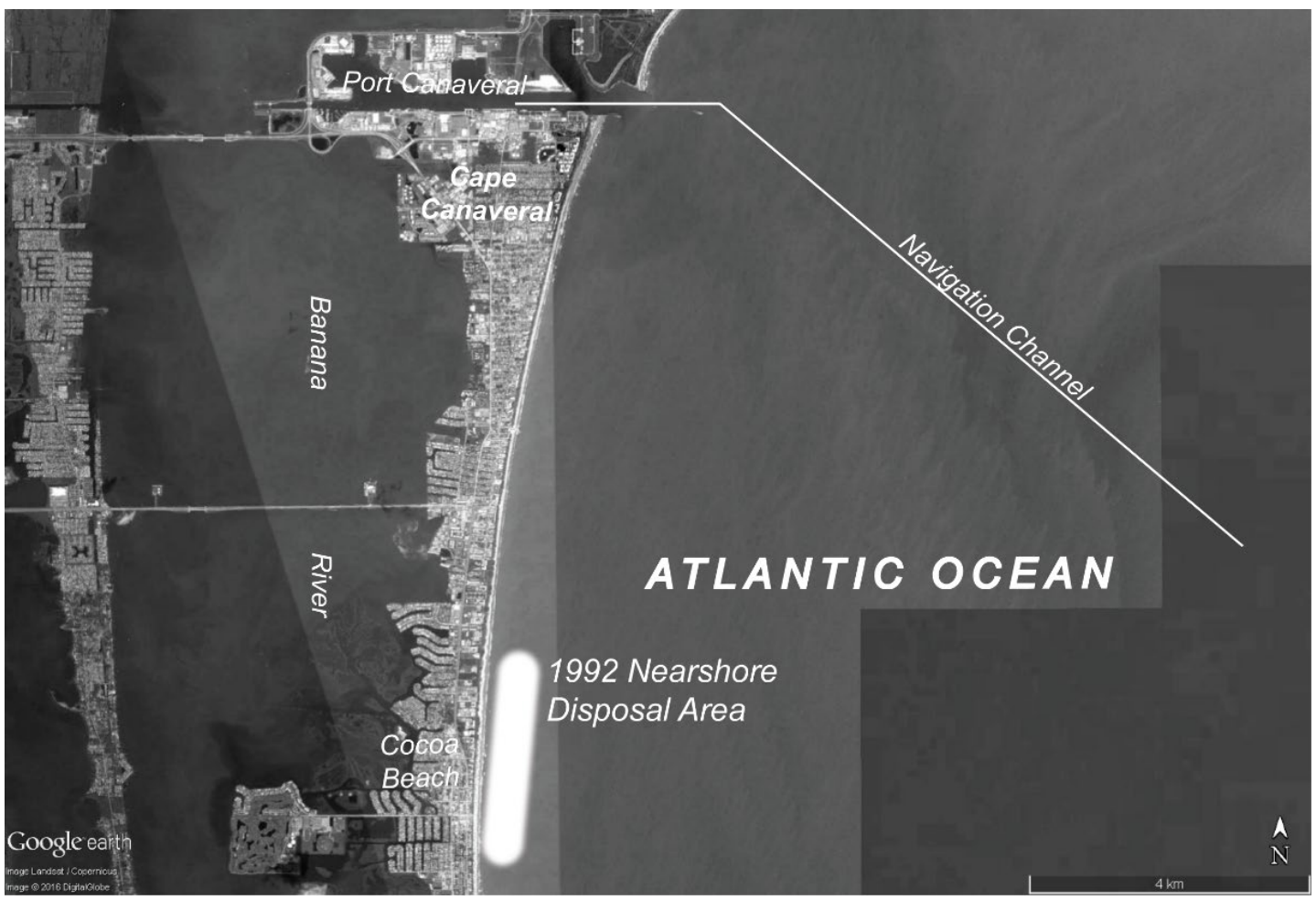




\subsubsection{Hydrographic description}

One year of offshore acoustic Doppler current profiler measurements ( $5 \mathrm{~km}$ east of Cocoa Beach; $15 \mathrm{~m}$ water depth) from 2003 to 2004 showed depth-averaged currents in the area rarely exceeded $0.25 \mathrm{~m} / \mathrm{s}$ and were directed toward the north and the south, though northerly currents occur twice as frequently (McArthur and Parsons 2005). In the same period, median near-bottom velocities measured $0.06 \mathrm{~m} / \mathrm{s}$ and were directed toward the northwest (McArthur and Parsons 2005).

Analysis of WIS data (Station 63439) during the berm's monitoring period (July 1992 - March 1993) revealed that waves were predominately from the east with a mean wave height of $1.2 \mathrm{~m}$ and $9 \mathrm{~s}$ average wave period (Table 2-7).

\subsubsection{Monitoring and berm evolution}

Four post-placement surveys were conducted over an 11-month timespan. Additional surveys were conducted outside of the placement area to capture changes to the background seabed profile. Investigation of the survey profiles and corresponding volumetric centroid positions confirmed that the berm overwhelmingly migrated landward; Bodge (1994) described it as cross-shore diffusion and shoreward-directed convection, as the berm's crest position remained in place even though the centroid migrated landward. Much of the sediment was transported rapidly for depths greater than $6.9 \mathrm{~m}$ MLW. The first survey, conducted 5 weeks after placement, showed that the berm's centroid migrated $30 \mathrm{~m}$ landward then slowed over the next 10 months, migrating another 9-15 $\mathrm{m}$. Total onshore migration was approximately $60 \mathrm{~m}$. No substantial sediment transport was detected for placement depths below 7.6 m MLW. Likewise, there was no detection of transport in the longshore direction. 
Table 2-7. Summary characteristics table for Port Canaveral, Florida.

\begin{tabular}{|c|c|c|c|c|c|c|c|c|}
\hline $\begin{array}{c}\text { Monitoring } \\
\text { Dates }\end{array}$ & \multicolumn{2}{|c|}{$\begin{array}{c}7 / 28 / 92- \\
7 / 1 / 93\end{array}$} & & & & & & \\
\hline $\begin{array}{l}\text { Placement } \\
\text { Volume } \\
\left(\mathrm{m}^{3}\right)\end{array}$ & \multicolumn{2}{|c|}{$\begin{array}{c}\text { Berm } \\
\text { Dimensions (m) } \\
(I \times w)\end{array}$} & $\begin{array}{c}\text { Water } \\
\text { Depth }(m)\end{array}$ & \multicolumn{2}{|c|}{$\begin{array}{l}\text { Berm } \\
\text { Relief } \\
(\mathrm{m})\end{array}$} & \multicolumn{2}{|c|}{$\begin{array}{l}\text { Mean } \\
\text { Sand } \\
\text { Size } \\
(\mathrm{mm})\end{array}$} & $\begin{array}{l}\text { Observed } \\
\text { Berm } \\
\text { Migration }\end{array}$ \\
\hline 121,000 & \multicolumn{2}{|c|}{$360 \times 180$} & $4.6-5.5$ & \multicolumn{2}{|c|}{2.1} & \multicolumn{2}{|c|}{0.25} & Onshore \\
\hline \multicolumn{9}{|c|}{ SMT Input Parameters } \\
\hline $\begin{array}{l}\text { WIS } \\
\text { Station }\end{array}$ & $\begin{array}{l}\text { WIS } \\
\text { Depth } \\
\text { (m) }\end{array}$ & $\begin{array}{c}\text { Shoreline } \\
\text { Angle }\end{array}$ & $\begin{array}{c}\text { Assumed } \\
\text { Longshore } \\
\text { Current } \\
(\mathrm{m} / \mathrm{s})\end{array}$ & $\begin{array}{l}\text { Average } \\
\text { Wave } \\
\text { Height } \\
\text { (m) }\end{array}$ & & & $\begin{array}{c}\text { Wave } \\
\text { Vector } \\
\text { (deg) }\end{array}$ & $\begin{array}{l}\text { Average } \\
\text { Wind } \\
\text { Direction } \\
\text { (deg) }\end{array}$ \\
\hline 63439 & 17 & 198 & 0.05 & 1.3 & & & 91 & 90 \\
\hline
\end{tabular}

\subsubsection{SMT results}

Results from the SMT (Figure 2-9) predict that this site is very favorable for onshore berm migration with very high frequency of mobility scores and mean mobility scores for all specified grain sizes (Table 2-8). The critical shear stress and velocity for the median grain size of placed material $(0.44 \mathrm{~mm}$ ) was 0.23 Pascal $(\mathrm{Pa})$ and $0.23 \mathrm{~m} / \mathrm{s}$, respectively. The predicted frequency of mobility is $97 \%$ and $99 \%$ using either bed stress or nearbottom velocity criteria, respectively. Likewise, the mean mobility scores indicate that the average excess shear stress and velocity was 4 and 3 times greater than critical values. At a depth of $6 \mathrm{~m}$, the probability of grain sizes between 0.3 and $0.5 \mathrm{~mm}$ to migrate onshore is $100 \%$, and $86 \%$ for $0.2 \mathrm{~mm}$ (Table 2-8). Conversely, $84 \%$ of the wave conditions favor offshore transport of sediments $0.1 \mathrm{~mm}$ or less (Table 2-8); thus, the winnowing and transport of fines out of the area is generally expected here. The median grain size and fines fraction of the dredged material during ( $0.4 \mathrm{~mm} ; 2.8 \%)$ and 10 months after placement $(0.4 \mathrm{~mm} ; 3.3 \%)$ were nearly identical. 
Figure 2-9. Distribution of maximum bed shear stress (top) and near-bottom velocities (bottom) for site Port Canaveral, Florida (WIS station 63439). $N$ is the number of hourly wave heights in each bin during the monitoring period.

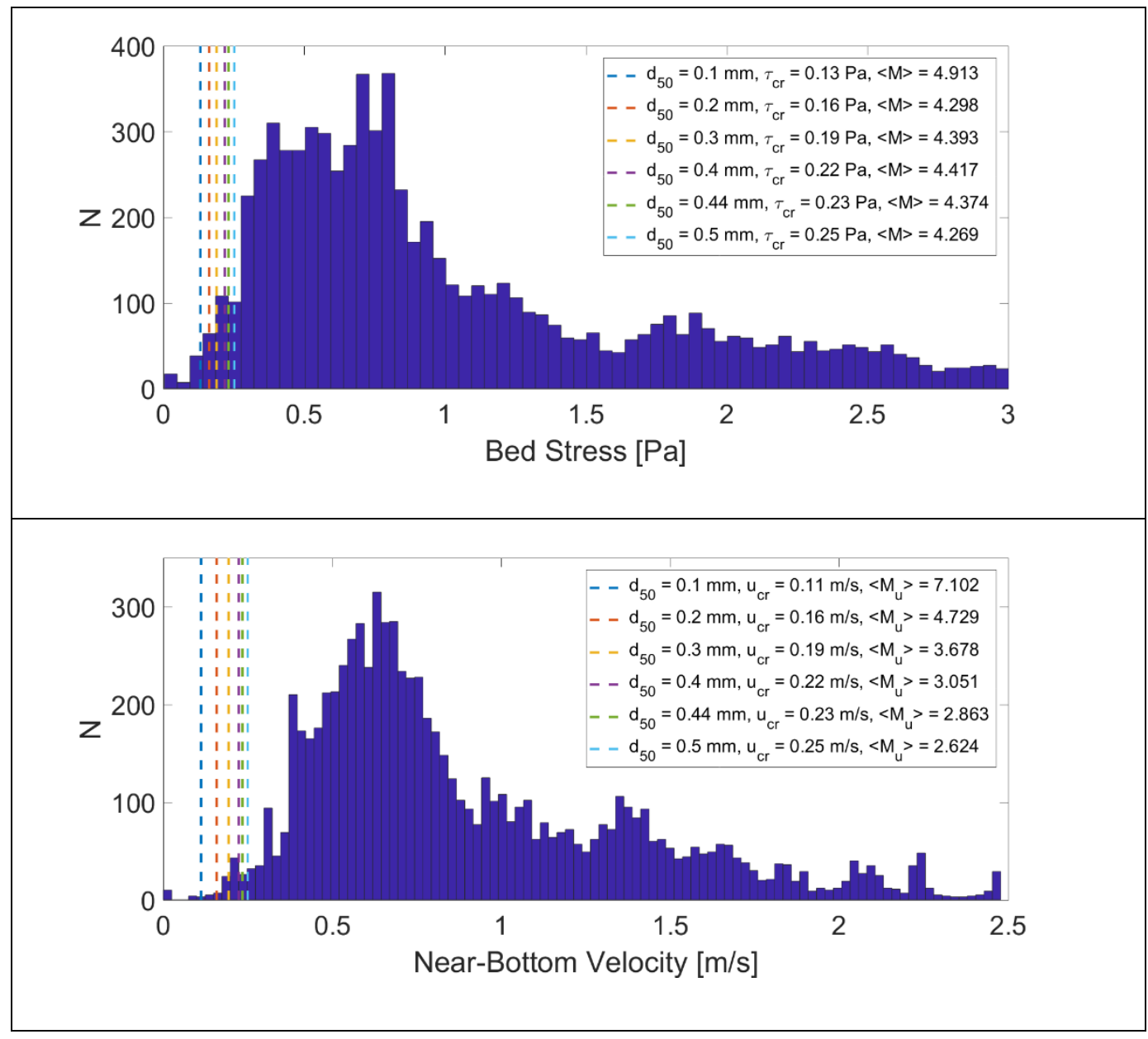

Table 2-8. Port Canaveral frequency of mobilization and predicted sediment migration for indicated grain sizes. Median grain size of placed material in bold.

\begin{tabular}{|c|c|c|c|}
\hline & Bed Shear Stress & Near-Bottom Velocity & \\
\hline $\begin{array}{c}d_{50} \\
(m m)\end{array}$ & $\begin{array}{c}\text { Frequency of } \\
\text { Mobilization }\left(\mathbf{F}_{\mathbf{M}}\right)\end{array}$ & $\begin{array}{c}\text { Frequency of } \\
\text { Mobilization }\left(\mathbf{F}_{\mathbf{M u}}\right)\end{array}$ & $\begin{array}{l}\text { Predicted Sediment } \\
\text { Migration }\end{array}$ \\
\hline 0.1 & $100 \%$ & $100 \%$ & $84 \%$ Offshore \\
\hline 0.2 & $98 \%$ & $100 \%$ & $86 \%$ Onshore \\
\hline 0.3 & $97 \%$ & $99 \%$ & $100 \%$ Onshore \\
\hline 0.4 & $97 \%$ & $99 \%$ & $100 \%$ Onshore \\
\hline 0.44 & $97 \%$ & $99 \%$ & $100 \%$ Onshore \\
\hline 0.5 & $97 \%$ & $99 \%$ & 100\% Onshore \\
\hline
\end{tabular}




\subsection{Site 5: Perdido Key, Florida (1991)}

\subsubsection{Site description and berm construction}

Perdido Key is part of the northwest barrier island chain of the Florida panhandle, just west of Pensacola Bay. In October of 1991, approximately 3 million $\mathrm{m}^{3}$ (3.9 million $\mathrm{yd}$ 3) of material dredged from the navigation channel of Pensacola Bay was placed in the nearshore area off the coast of Perdido Key (Figure 2-10); Pensacola pass inlet is located approximately $4 \mathrm{~km}$ east of the berm's centroid. Placement depths ranged from 5 to $6.5 \mathrm{~m}$ at an offshore distance between 500 to $1300 \mathrm{~m}$. The berm length was $3.75 \mathrm{~km}$, and the berm width ranged from $300 \mathrm{~m}$ at the western end to $800 \mathrm{~m}$ at the eastern end (Table 2-9). The berm was constructed in a flat region of the offshore zone (1:1000 slope) seaward of a 1:20 sloped foreshore; the berm relief was $1.5 \mathrm{~m}$. The median grain size of the dredged material was $0.3 \mathrm{~mm}$ with slightly finer sediments offshore.

Figure 2-10. Location map of the 1991 Perdido Key, Florida placement site. Image date 2015.

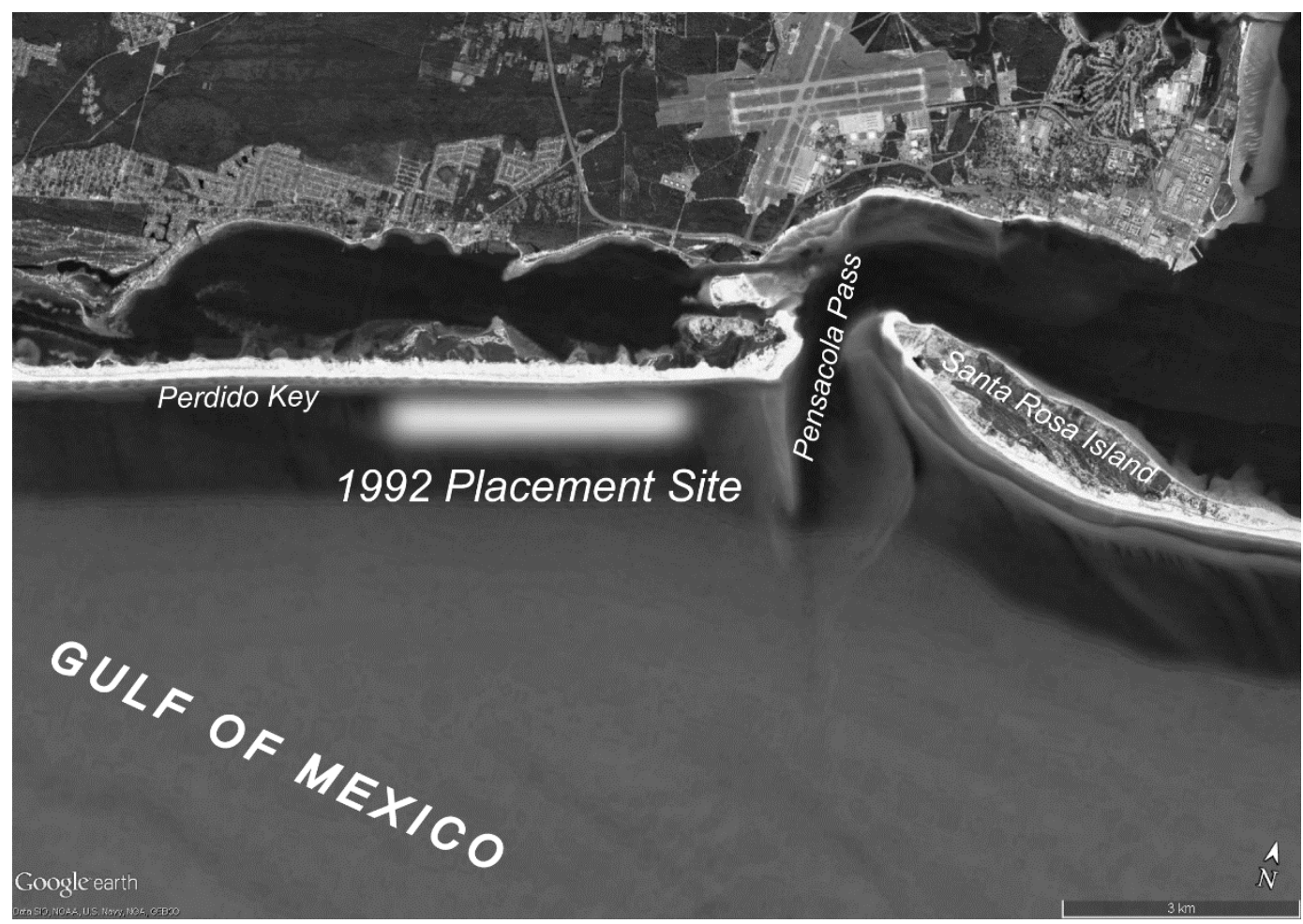




\subsubsection{Hydrographic description}

Waves, currents, and tides were measured near the berm site over a 2-year duration (Otay 1994). One directional wave gage was mounted in $7 \mathrm{~m}$ water depth, $750 \mathrm{~m}$ offshore, and $4 \mathrm{~km}$ west of the western end of the berm. The other was placed in $5 \mathrm{~m}$ water depth, $1 \mathrm{~km}$ offshore near the eastern end of the berm area. Predominate wave directions were from the south and east-southeast (5 degrees [ deg] and 50 deg from shore normal). The most frequently occurring wave heights were $0.21-0.28 \mathrm{~m}$, and average wave heights were on the order of $0.5-0.6 \mathrm{~m}$ with $6 \mathrm{~s}$ wave periods. Wave heights exceeding $1 \mathrm{~m}$ occurred less than $5 \%$ of the time.

Mean current velocities were $0.08 \mathrm{~m} / \mathrm{s}$ at the far western boundary and $0.11 \mathrm{~m} / \mathrm{s}$ at the eastern boundary. Currents at the eastern boundary were found to be most energetic in the onshore direction. Maximum velocities recorded during the monitoring period were less than $0.4 \mathrm{~m} / \mathrm{s}$.

Estimates of net longshore sediment transport in the vicinity (from 19761995) are highly variable $\left(38,000-352,000 \mathrm{~m}^{3}\right)$ and average $187,000 \mathrm{~m}^{3}$ to the west (Browder and Dean 1999).

\subsubsection{Monitoring and berm evolution}

Conditions at this site were initially thought to be conducive to onshore migration, yet surveys showed that the center of gravity of the berm remained stable with only lateral spreading of sediments. The average elevation of the berm did not change more than $\pm 9 \mathrm{~cm}$. The berm did provide shoreline protection, however, as the shoreline recession of the sheltered area was $35 \mathrm{~m}$ compared to $60 \mathrm{~m}$ outside of it during the monitoring period (Otay 1994). 
Table 2-9. Summary characteristics table for Perdido Key, Florida (1991).

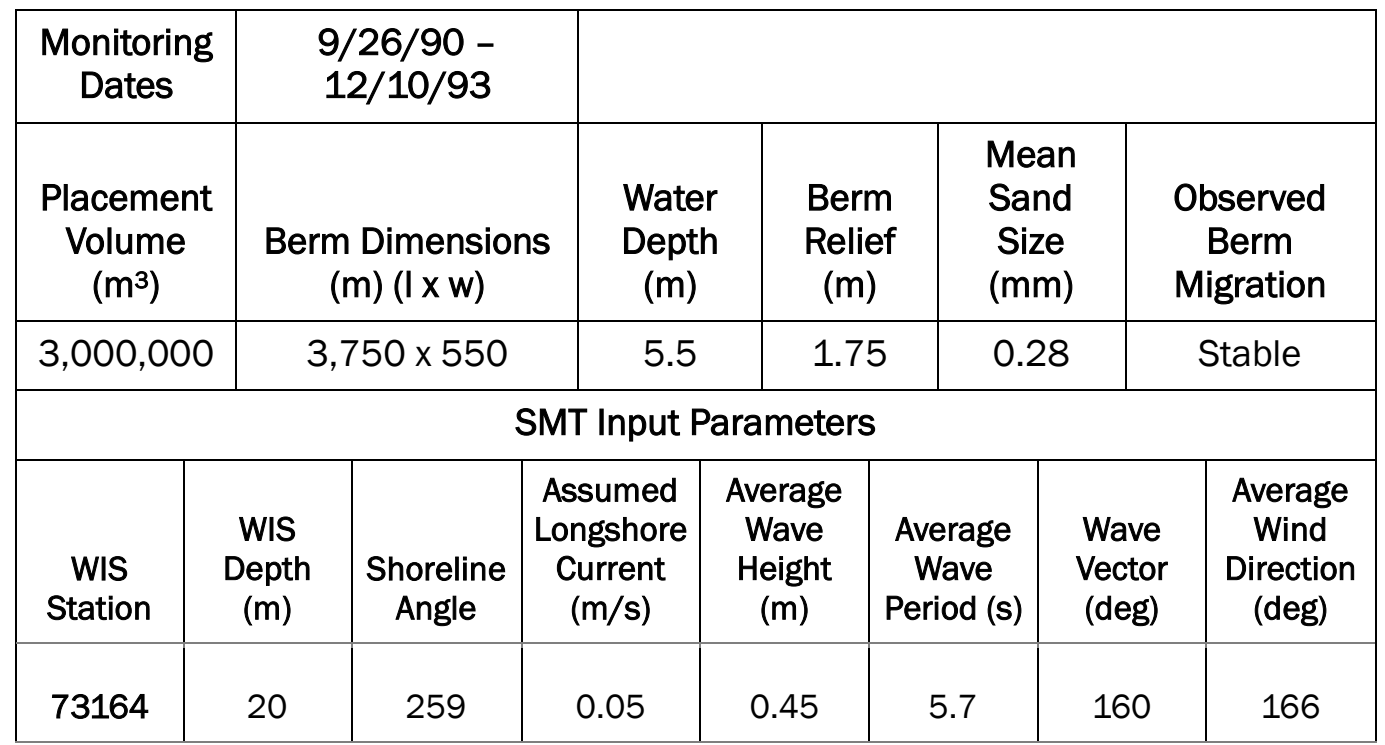

\subsubsection{SMT results}

Results of the SMT are presented in Figure 2-11. In contrast to the initial expectation, and based on the low frequencies of mobility scores (Table 2-10), the SMT results show that sediments are not predicted to mobilize very often for grain sizes representative of the berm (36$47 \%$ for $\left.d_{50}=0.28\right)$. Cross-shore migration is predicted in the onshore direction for all grain sizes (Table 2-10); however, the mean mobility scores are less than 1 . This is a good indicator that the berm will actually be stable, as was also observed at the outer mound at Mobile, Alabama. 
Figure 2-11. Distribution of maximum bed shear stress (top) and near-bottom velocities (bottom) for site Perdido Key (1991), Florida (WIS station 73164). $N$ is the number of hourly wave heights in each bin during the monitoring period.

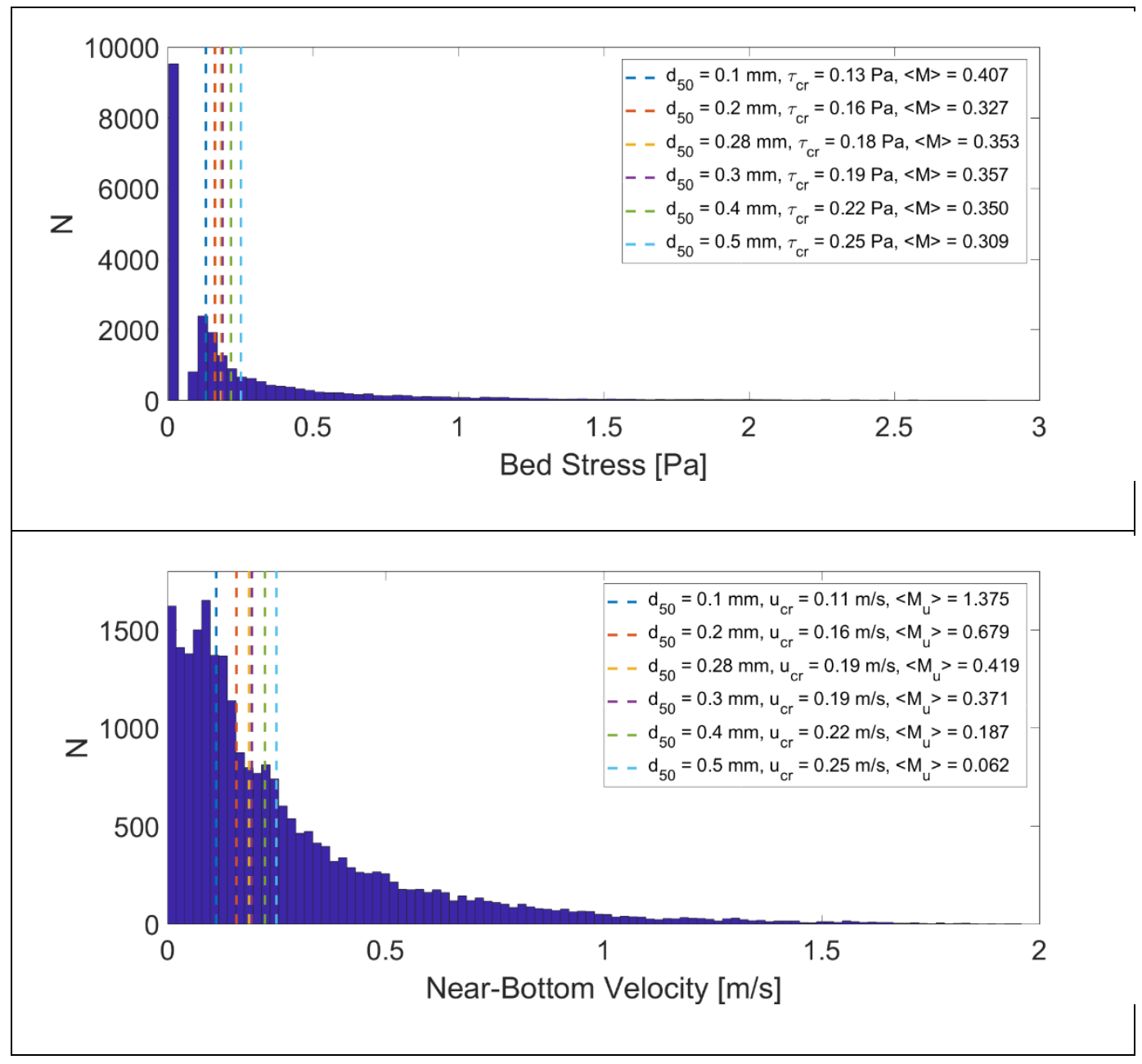

Table 2-10. Perdido Key (1991) frequency of mobilization and predicted sediment migration for indicated grain sizes. Median grain size of placed material in bold.

\begin{tabular}{|c|c|c|c|}
\hline $\begin{array}{c}\text { d50 } \\
(\mathbf{m m})\end{array}$ & $\begin{array}{c}\text { Bed Shear Stress } \\
\text { Mobilization }\left(\boldsymbol{F}_{\boldsymbol{M}}\right)\end{array}$ & $\begin{array}{c}\text { Near-Bottom Velocity } \\
\text { Frequency of } \\
\text { Mobilization }\left(\boldsymbol{F}_{\boldsymbol{M u}}\right)\end{array}$ & $\begin{array}{c}\text { Predicted Sediment } \\
\text { Migration }\end{array}$ \\
\hline 0.1 & $48 \%$ & $64 \%$ & $58 \%$ Onshore \\
\hline 0.2 & $41 \%$ & $52 \%$ & $96 \%$ Onshore \\
\hline 0.28 & $36 \%$ & $47 \%$ & $99 \%$ Onshore \\
\hline 0.3 & $36 \%$ & $46 \%$ & $100 \%$ Onshore \\
\hline 0.4 & $36 \%$ & $41 \%$ & $100 \%$ Onshore \\
\hline 0.5 & $36 \%$ & $36 \%$ & $100 \%$ Onshore \\
\hline
\end{tabular}




\subsection{Site 6: Newport Beach, California (1992)}

\subsubsection{Site description and berm construction}

In the vicinity of Newport Beach, California, natural sediment supply from the Santa Ana River and coastal bluffs to the San Pedro littoral cell was interrupted following early twentieth century coastal development and construction of flood control structures (Wiegel 2009). The area has been subjected to periodic nourishment projects since 1964. In 1992, nearly 1.o million $\mathrm{m}^{3}$ of dredged material was placed in the nearshore environment, selected to confine sediments between the jettied Santa Ana River to the south and a groin field to the north (Figure 2-12). The disposal area was approximately $900 \mathrm{~m}$ in length and $335 \mathrm{~m}$ in width located approximately $90 \mathrm{~m}$ offshore between the $1.5 \mathrm{~m}$ and $8 \mathrm{~m}$ depth contours (relative to MLLW). Instead of a berm, the placement was constructed as a series of mounds throughout the disposal area. The dredged material consisted of $83 \%$ sand and $17 \%$ fines with a median diameter of $0.27 \mathrm{~mm}$. The native sediments were described as a poorly graded fine sand (83\%) with $17 \%$ fines and a median grain size of $0.09 \mathrm{~mm}$ (Mesa 1997). Over the course of the project's monitoring, the fine sands had winnowed to $2 \%$ (Mesa 1997).

Figure 2-12. Location map of Newport Beach placement site, California. Image date 2016.

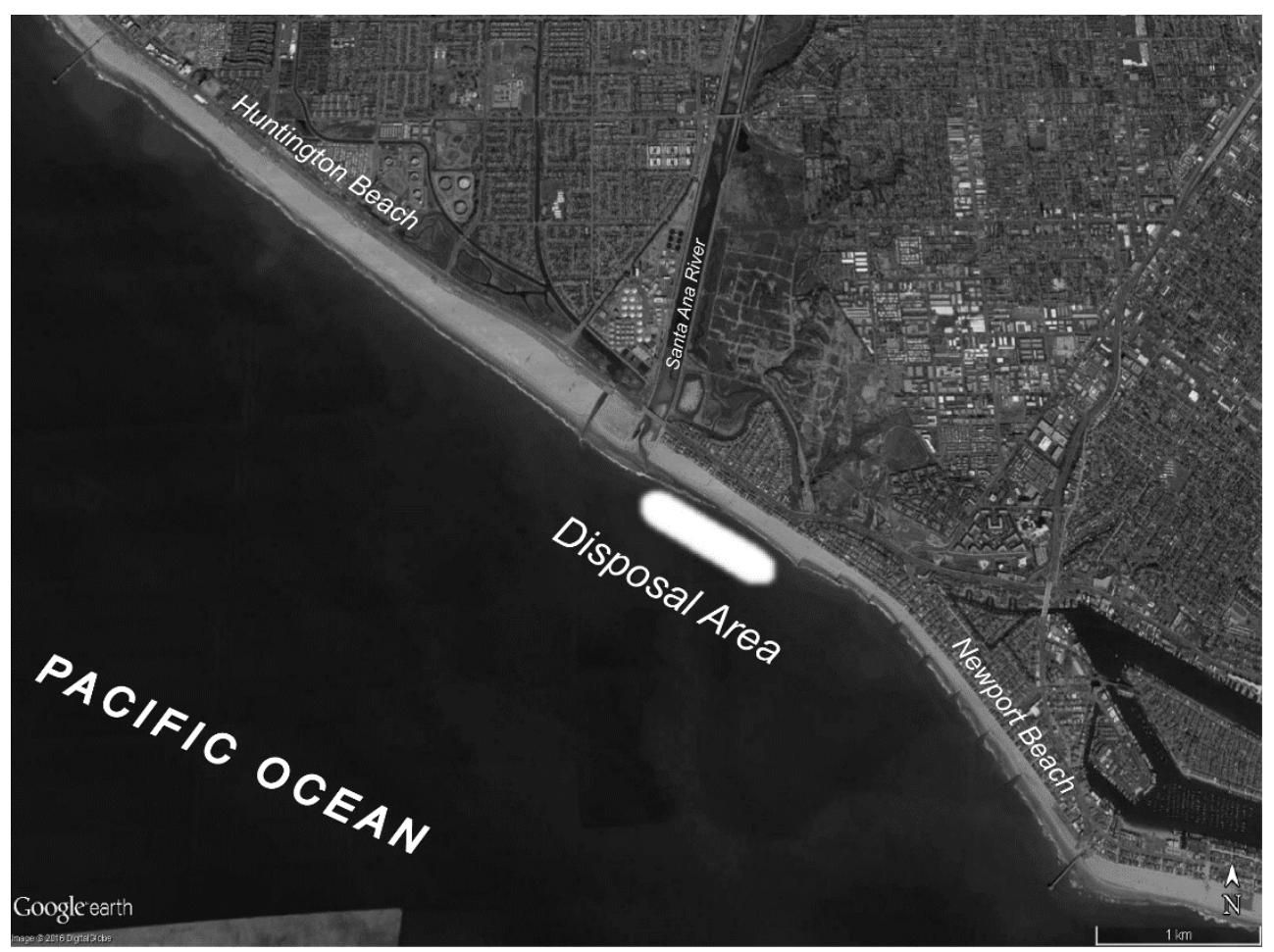




\subsubsection{Hydrographic description}

The directional wave climate was measured $2.4 \mathrm{~km}$ miles offshore in a water depth of $10 \mathrm{~m}$. The mean wave height was reported as $0.82 \pm 0.3 \mathrm{~m}$ (one standard deviation) with a maximum of $3.2 \mathrm{~m}$ (Table 2-11). Wave periods were bimodal, $7 \mathrm{~s}$ and $15 \mathrm{~s}$, associated with sea and swell conditions, respectively. Analysis of WIS data during the monitoring period showed good agreement that waves typically approach from the west with a mean wave height of $0.77 \mathrm{~m}$ and $10 \mathrm{~s}$ wave period.

\subsubsection{Monitoring and berm evolution}

Repeated cross-shore profiles revealed that over a 31-month period, sediments were dispersed landward through erosion of the berm's crest, the relief of which reduced from $4.4 \mathrm{~m}$ to $2.4 \mathrm{~m}$. Berm categorization based on Hands and Allison (1991) classified it as being stable for a typical wave climate and active for wave conditions approaching the 99th percentile. The method of Hallermeier (1981b) classified the berm as weakly active to active within the buffer zone of the inner and outer depth limits. Coincidently, the surveys clearly showed that while sediments accumulated toward the shore, the base and centroid of the berm remained relatively stable. Further, there was no indication of any offshore movement (Mesa, 1997). The adjacent beach was reported to increase in width near the mound from approximately $84 \mathrm{~m}$ to $100 \mathrm{~m}$ over the following 2-3 years (CBRS 2002).

Table 2-11. Summary characteristics table for Newport Beach, California.

\begin{tabular}{|c|c|c|c|c|c|c|c|c|}
\hline $\begin{array}{l}\text { Monitoring } \\
\text { dates }\end{array}$ & \multicolumn{3}{|c|}{$\begin{array}{c}\text { 05/1992 - } \\
05 / 1995\end{array}$} & & & & & \\
\hline $\begin{array}{l}\text { Placement } \\
\text { Volume } \\
\left(\mathrm{m}^{3}\right)\end{array}$ & \multicolumn{3}{|c|}{$\begin{array}{l}\text { Berm Dimensions } \\
\quad(\mathrm{m})(\mathrm{I} \times \mathrm{w})\end{array}$} & $\begin{array}{c}\text { Water } \\
\text { Depth } \\
(\mathrm{m})\end{array}$ & \multicolumn{2}{|c|}{$\begin{array}{c}\text { Berm } \\
\text { Relief (m) }\end{array}$} & $\begin{array}{c}\text { Mean } \\
\text { Sand } \\
\text { Size } \\
(\mathrm{mm})\end{array}$ & $\begin{array}{c}\text { Observed } \\
\text { Berm } \\
\text { Migration }\end{array}$ \\
\hline 976,000 & \multicolumn{3}{|c|}{ Not reported } & 5.5 & \multicolumn{2}{|c|}{4.4} & 0.27 & Onshore \\
\hline \multicolumn{9}{|c|}{ SMT Input Parameters } \\
\hline $\begin{array}{l}\text { WIS } \\
\text { Station }\end{array}$ & $\begin{array}{l}\text { WIS } \\
\text { Depth } \\
\text { (m) }\end{array}$ & $\begin{array}{c}\text { Shoreline } \\
\text { Angle }\end{array}$ & $\begin{array}{r}\text { As } \\
\text { Lor } \\
\text { C } \\
(\end{array}$ & $\begin{array}{l}\text { Imed } \\
\text { shore } \\
\text { rent } \\
\text { /s) }\end{array}$ & $\begin{array}{c}\text { Average } \\
\text { Wave } \\
\text { Height } \\
\text { (m) }\end{array}$ & $\begin{array}{l}\text { Avera } \\
\text { Wav } \\
\text { Perioc }\end{array}$ & $\begin{array}{l}\text { Wave } \\
\text { Vector } \\
\text { (deg) }\end{array}$ & $\begin{array}{l}\text { Average } \\
\text { Wind } \\
\text { Direction } \\
\text { (deg) }\end{array}$ \\
\hline 83102 & 467 & 303 & & .1 & 0.82 & $7-1$ & 262 & 291 \\
\hline
\end{tabular}




\subsubsection{SMT results}

The SMT results (Figure 2-13) predicted that sediments placed at $1.7 \mathrm{~m}$ depth would only slowly move onshore based on the slightly elevated frequency of sediment mobility $\left(f_{M}=60 \%\right)$ for the reported median grain size of $0.27 \mathrm{~mm}$ (Table 2-12). The bottom shear stress was on average $35 \%$ greater than the critical stress of $0.18 \mathrm{~Pa}$. However, sediment mobility based on near-bottom velocities predict a much greater frequency of mobility $\left(f_{M u}=98 \%\right)$. Cross-shore migration was predicted to be overwhelmingly onshore (Table 2-12) for the considered grain sizes $(0.1-0.5 \mathrm{~mm})$ though the velocity-based mobility score $\left(M_{u}=3.2\right)$ was very high suggesting a winnowing of finer sediments, which matched observations. 
Figure 2-13. Distribution of maximum bed shear stress (top) and near-bottom velocities (bottom) for site Newport Beach, California (WIS station 83102) $N$ is the number of hourly wave heights in each bin during the monitoring period.

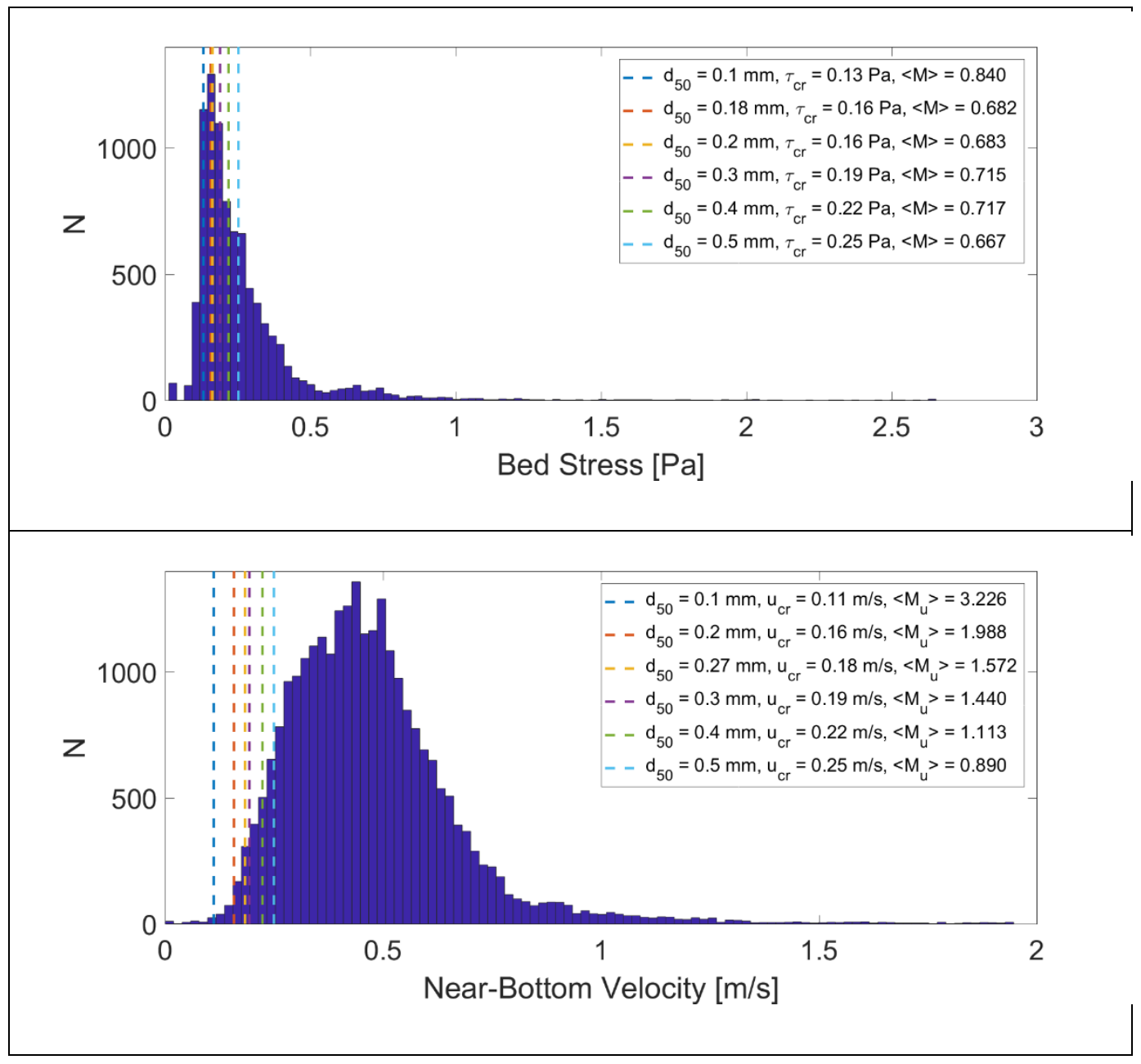

Table 2-12. Perdido Key (1991) frequency of mobilization and predicted sediment migration for indicated grain sizes. Median grain size of placed material in bold.

\begin{tabular}{|c|c|c|c|}
\hline $\begin{array}{c}\text { d50 } \\
(\mathbf{m m})\end{array}$ & $\begin{array}{c}\text { Bed Shear Stress } \\
\text { Mobilization }\left(\boldsymbol{F}_{\boldsymbol{M}}\right)\end{array}$ & $\begin{array}{c}\text { Near-Bottom Velocity } \\
\text { Mrequency of } \\
\text { Mobilization }\left(\boldsymbol{F}_{\boldsymbol{M} \boldsymbol{u}}\right)\end{array}$ & $\begin{array}{c}\text { Predicted Sediment } \\
\text { Migration }\end{array}$ \\
\hline 0.1 & $75 \%$ & $100 \%$ & $85 \%$ Onshore \\
\hline 0.2 & $58 \%$ & $99 \%$ & $100 \%$ Onshore \\
\hline 0.27 & $60 \%$ & $98 \%$ & $100 \%$ Onshore \\
\hline 0.3 & $61 \%$ & $98 \%$ & $100 \%$ Onshore \\
\hline 0.4 & $62 \%$ & $95 \%$ & $100 \%$ Onshore \\
\hline 0.5 & $60 \%$ & $92 \%$ & $100 \%$ Onshore \\
\hline
\end{tabular}




\subsection{Site 7: Brunswick, Georgia "Mound C" (2003)}

Maintenance dredging of the Brunswick Harbor navigation channel produced a series of disposal mounds along its length (Figure 2-14). Of these, Mound C was selected for study by Johnson (2005) to track mound movement concurrent with hydrodynamic measurements and to predict medium term transport trends. Mound $\mathrm{C}$ was located $8 \mathrm{~km}$ offshore of Jekyll Island in 6-8 $\mathrm{m}$ of water and had a relief of 4-5 $\mathrm{m}$. The mound was crescent shaped and had dimensions of approximately $600 \times 600 \mathrm{~m}$. The median grain size of the mound was $0.35 \mathrm{~mm}$; sediments in the vicinity were reported to be $93 \%$ sand, $4 \%$ gravel, and $3 \%$ silt and clay (McArthur and Parsons 2005).

Figure 2-14. Location map of placement site Brunswick, Georgia, “Mound C.” Image date 2016.

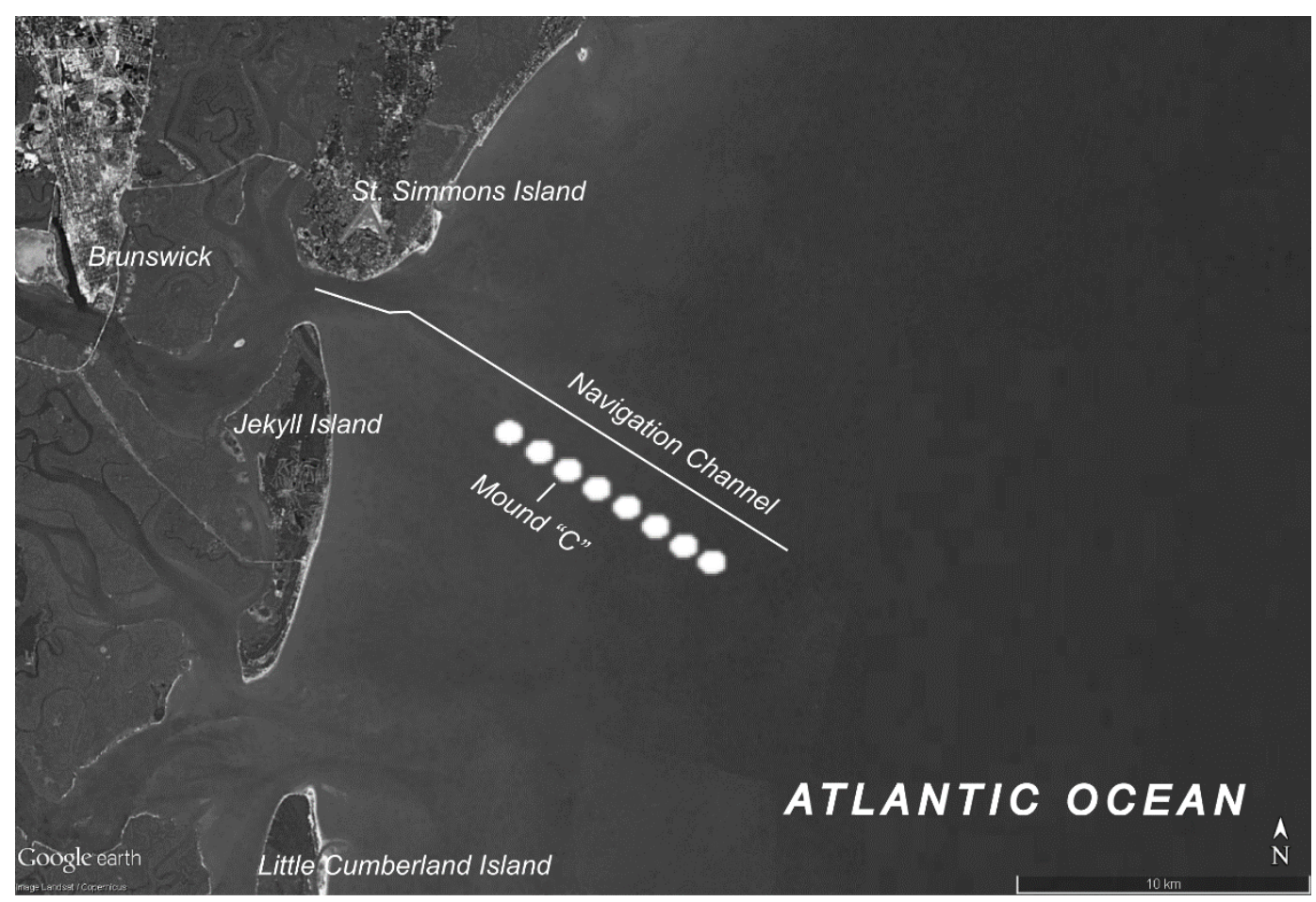

\subsubsection{Hydrographic description}

The Georgia Bight region is considered tidally dominated with a semidirunal tidal range of $2 \mathrm{~m}$ and spring tides up to $3 \mathrm{~m}$. Mean wave heights measured at Grays Reef Buoy (approximately $50 \mathrm{~km}$ north of the study site) ranged from $0.80 \pm 0.34 \mathrm{~m}$ in the summer to $1.1 \pm 0.5 \mathrm{~m}$ in the fall and winter months. During the monitoring period, waves measured adjacent to the mound were reported to be on the order of $0.5 \mathrm{~m}$ with wave 
directions typically from the southeast $\left(105^{\circ}\right)$; it was estimated that only $2 \%$ of these waves met the wave breaking criteria (Johnson 2005). The large tidal range gives rise to swift currents, which measured an average of 0.22-0.27 m/s in the direction parallel to the channel axis (Johnson 2005). Conversely, currents perpendicular to the channel measured less than $0.01 \mathrm{~m} / \mathrm{s}$. Summary characteristics are provided in Table 2-13.

\subsubsection{Monitoring and berm evolution}

Fluorescent tracers $\left(d_{50}=0.24 \mathrm{~mm}\right)$ placed on the crest of the mound revealed that sediments moved parallel to the channel and biased toward the onshore direction. Additionally, small tracers in the fines class $\left(d_{50}=\right.$ $0.065 \mathrm{~mm}$ ) were winnowed out quickly (days to weeks). Differences in bathymetric survey data suggested the mound deflated at a rate of $20-45 \mathrm{~cm} /$ month with net migration of the tracers depositing toward the southwest direction (i.e., slightly onshore). It was determined that both waves and currents played a role in sediment transport. A detailed tracer study by Smith et al. (2007) revealed that net sand tracer movement was to the southwest, away from the navigation channel. The observed sediment transport towards the southwest while the waves are from the southeast could be attributed to vessel wakes influencing the sediment direction, or could indicate the influence of the navigation channel parallel tidal currents.

Table 2-13. Summary characteristics table for Brunswick, Georgia.

\begin{tabular}{|c|c|c|c|c|c|c|c|}
\hline \multicolumn{2}{|c|}{$\begin{array}{l}\text { Monitoring } \\
\text { Dates }\end{array}$} & \multicolumn{2}{|c|}{$\begin{array}{c}01 / 2003- \\
09 / 2003\end{array}$} & & & & \\
\hline \multicolumn{2}{|c|}{$\begin{array}{c}\text { Placement } \\
\text { Volume }\left(\mathrm{m}^{3}\right)\end{array}$} & \multicolumn{2}{|c|}{$\begin{array}{l}\text { Berm Dimensions } \\
\quad(\mathrm{m})(\mathrm{I} \times \mathrm{x})\end{array}$} & $\begin{array}{l}\text { WATER } \\
\text { Depth } \\
(\mathrm{m})\end{array}$ & $\begin{array}{c}\text { BERM } \\
\text { Relief } \\
(\mathrm{m})\end{array}$ & $\begin{array}{l}\text { Mean } \\
\text { Sand } \\
\text { Size } \\
(\mathrm{mm})\end{array}$ & $\begin{array}{l}\text { Observed } \\
\text { Berm } \\
\text { Migration }\end{array}$ \\
\hline \multicolumn{2}{|c|}{$n / a$} & $600 \times 6$ & 600 & 6 & $4-5$ & 0.35 & Onshore \\
\hline \multicolumn{8}{|c|}{ SMT Parameters } \\
\hline $\begin{array}{l}\text { WIS } \\
\text { Station }\end{array}$ & $\begin{array}{l}\text { WIS } \\
\text { Depth } \\
\text { (m) }\end{array}$ & $\begin{array}{c}\text { Shoreline } \\
\text { Angle }\end{array}$ & $\begin{array}{l}\text { Assumed } \\
\text { Longshore } \\
\text { Current } \\
(\mathrm{m} / \mathrm{s})\end{array}$ & $\begin{array}{c}\text { Average } \\
\text { Wave } \\
\text { Height } \\
\text { (m) }\end{array}$ & $\begin{array}{l}\text { Average } \\
\text { Wave } \\
\text { Period (s) }\end{array}$ & $\begin{array}{l}\text { Wave } \\
\text { Vector } \\
\text { (deg) }\end{array}$ & $\begin{array}{l}\text { Average } \\
\text { Wind } \\
\text { Direction } \\
\text { (deg) }\end{array}$ \\
\hline 63393 & 467 & 303 & 0.1 & 0.5 & $9.2^{*}$ & 105 & 138 \\
\hline
\end{tabular}




\subsubsection{SMT results}

The SMT results (Figure 2-15) show that for a depth of $6 \mathrm{~m}$ and a median grain size of $0.35 \mathrm{~mm}$, the frequency of waves exceeding the critical threshold for movement was $97 \%$ based on shear stress and $98 \%$ based on wave velocities (Table 2-14). The mean mobility scores indicate that average shear stresses and velocities were 2.5-4.0 times greater than critical thresholds for a range of grain sizes, and up to nearly 6 times greater for sediments less than $0.1 \mathrm{~mm}$, which supports the observed winnowing behavior of the fine sediment tracers. However, the onshore behavior predicted by the SMT was not observed in the field, likely because the placement was placed close to a navigation channel rather than a shoreline. Most of the morphological change observed was the dispersion of sediments from the mound crest to base of its margins. The SMT transforms waves from the offshore to the nearshore placement site and does not account for vessel wakes, which is likely very important for these mounds placed close to the navigation channel. 
Figure 2-15. Distribution of maximum bed shear stress (top) and near-bottom velocities (bottom) for site Brunswick, Georgia, "Mound C" (WIS station 63393). Nis the number of hourly wave heights in each bin during the monitoring period.

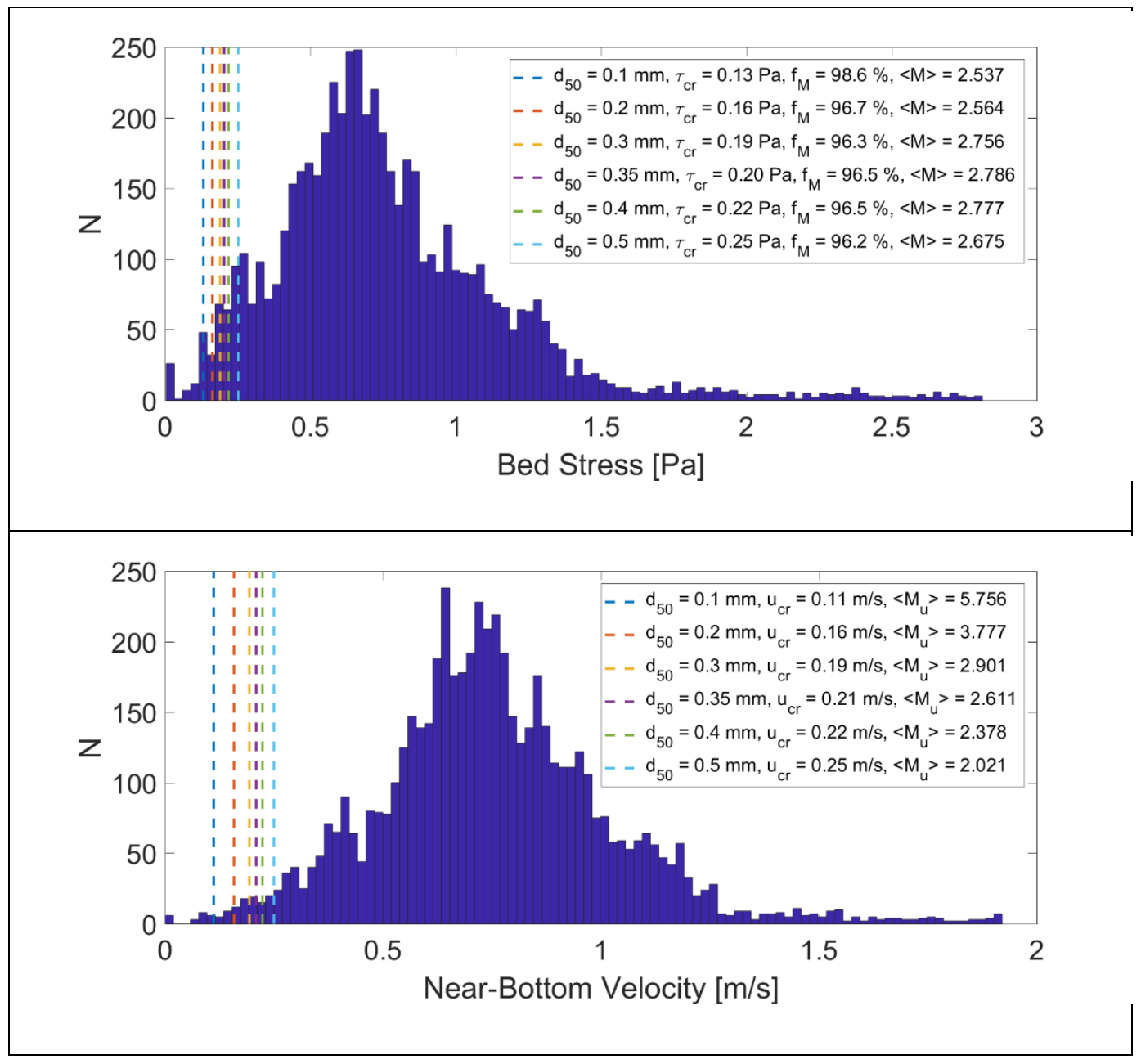

Table 2-14. Brunswick, Georgia frequency of mobilization and predicted sediment migration for indicated grain sizes. Median grain size of placed material in bold.

\begin{tabular}{|c|c|c|c|}
\hline $\begin{array}{c}\text { d50 } \\
(\mathbf{m m})\end{array}$ & $\begin{array}{c}\text { Bed Shear Stress } \\
\text { Mobilization }\left(\boldsymbol{F}_{\boldsymbol{M}}\right)\end{array}$ & $\begin{array}{c}\text { Near-Bottom Velocity } \\
\text { Fobilization }\left(\boldsymbol{F}_{\boldsymbol{M} \boldsymbol{u}}\right)\end{array}$ & $\begin{array}{c}\text { Predicted Sediment } \\
\text { Migration }\end{array}$ \\
\hline 0.1 & $99 \%$ & $100 \%$ & $85 \%$ Offshore \\
\hline 0.2 & $97 \%$ & $99 \%$ & $99 \%$ Onshore \\
\hline 0.3 & $96 \%$ & $99 \%$ & $100 \%$ Onshore \\
\hline 0.35 & $96 \%$ & $99 \%$ & $100 \%$ Onshore \\
\hline 0.4 & $96 \%$ & $98 \%$ & $100 \%$ Onshore \\
\hline 0.5 & $96 \%$ & $98 \%$ & $100 \%$ Onshore \\
\hline
\end{tabular}




\subsection{Site 8: Ocean Beach, California (2005)}

\subsubsection{Site descriptions and berm monitoring}

In 2005, 225,000 $\mathrm{m}^{3}$ of dredged material from the main shipping channel of San Francisco Bay was placed approximately $500 \mathrm{~m}$ offshore of a known erosional hotspot at Ocean Beach, California (Figure 2-16). The geometry of the placement was an irregular mound. Placement depths ranged from 9 to $14 \mathrm{~m}$. The dredged material had a median grain size of $0.18 \mathrm{~mm}$, similar to nearby nearshore bar sediments but significantly finer than the beach sand $\left(d_{50}=0.28 \mathrm{~mm}\right)$.

Fluctuations in shoreline position can exceed $80 \mathrm{~m}$ due to its high energy tidal and wave climate, and seasonal transitions of summer and winter profiles are typical (Barnard et al. 2009). South of the placement area, sand waves with wavelengths on the order of 5-10 m and crests near perpendicular to shore were observed; however, no bed forms were observed in the immediate vicinity of the berm (Barnard et al. 2009).

Figure 2-16. Location map of placement site Ocean Beach, California. Imagery courtesy of Google Earth. Image date 2016.

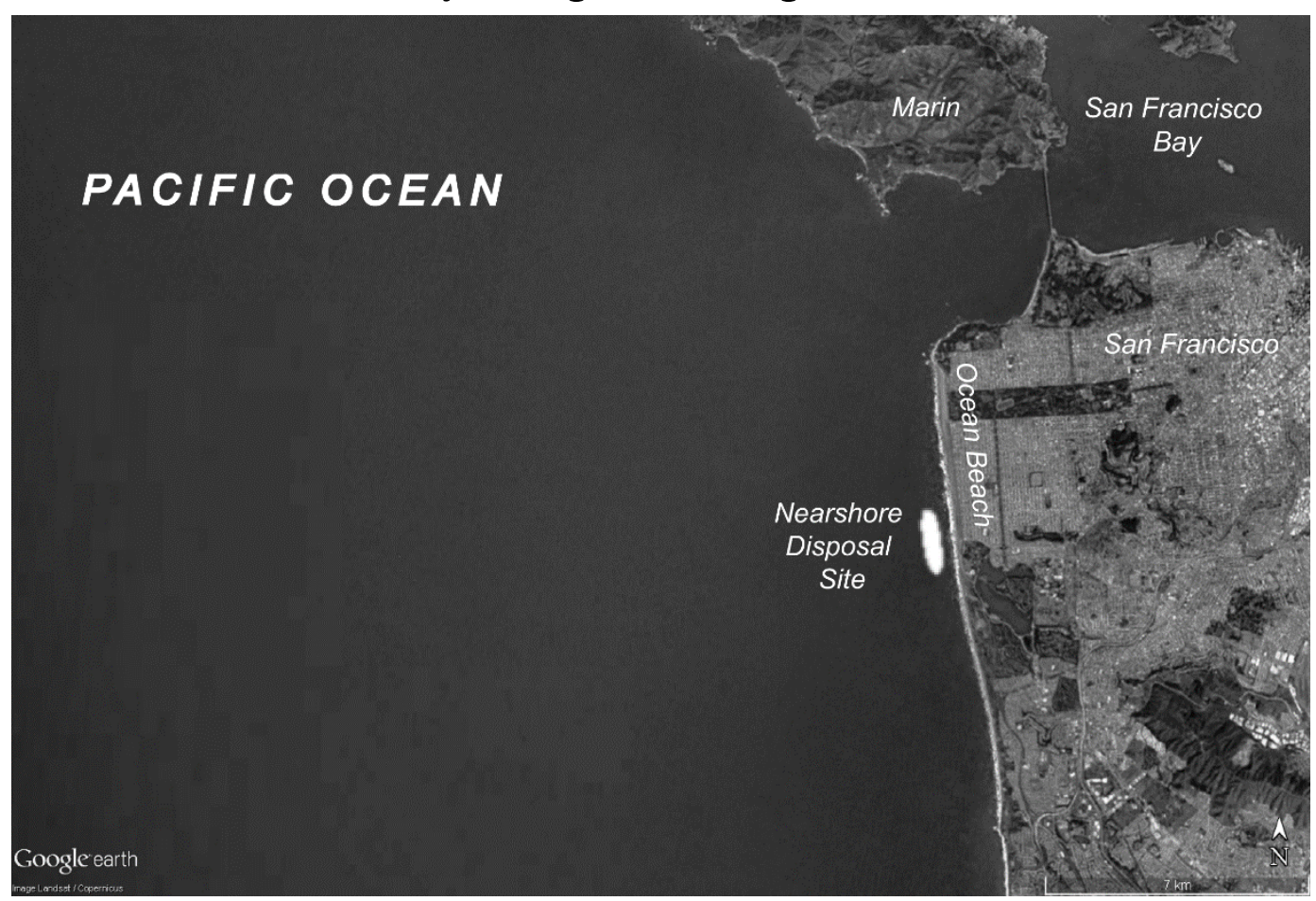




\subsubsection{Hydrographic description}

This area is known to be highly energetic in terms of both waves and tidal currents. Tidal currents produced from ebb and flood tides trend alongshore, peaking at $60-80 \mathrm{~cm} / \mathrm{s}$. Barnard et al. (2006) reported that waves measured near the mound showed wave heights could approach $2.5 \mathrm{~m}$, but no further information was given. Analysis of WIS data over the monitoring period revealed average wave heights of $1 \mathrm{~m}$ with 13 seconds wave periods approaching from the west. Summary characteristics are provided in Table 2-15.

\subsubsection{Monitoring and berm evolution}

Bathymetric monitoring results showed that the mound had greatly dispersed over the summer months. The crest of the mound moved $30 \mathrm{~m}$ onshore, but overall volume was reduced by 50\%. After one year the mound was even more dispersed and the peak of the mound had migrated $100 \mathrm{~m}$ shoreward. Beach accretion followed the initial placement, although whether it could be attributable to mound migration remained speculative.

Table 2-15. Summary characteristics table for Ocean Beach, California. Asterisks indicate values derived from WIS data over the indicated monitoring period.

\begin{tabular}{|c|c|c|c|c|c|c|c|}
\hline \multicolumn{2}{|c|}{ Monitoring Dates } & \multicolumn{2}{|c|}{$\begin{array}{c}05 / 2005- \\
05 / 2006\end{array}$} & & & & \\
\hline \multicolumn{2}{|c|}{$\begin{array}{l}\text { Placement } \\
\text { Volume }\left(\mathrm{m}^{3}\right)\end{array}$} & \multicolumn{2}{|c|}{$\begin{array}{l}\text { Berm Dimensions } \\
\quad(\mathrm{m})(\mathrm{I} \times \mathrm{w})\end{array}$} & $\begin{array}{c}\text { Water } \\
\text { Depth } \\
\text { (m) }\end{array}$ & $\begin{array}{c}\text { Berm } \\
\text { Relief } \\
(\mathrm{m})\end{array}$ & $\begin{array}{c}\text { Mean } \\
\text { Sand } \\
\text { Size } \\
(\mathrm{mm})\end{array}$ & $\begin{array}{l}\text { Observed } \\
\text { Berm } \\
\text { Migration }\end{array}$ \\
\hline \multicolumn{2}{|c|}{225,000} & \multicolumn{2}{|c|}{$\mathrm{n} / \mathrm{a}$} & 11.5 & $\mathrm{n} / \mathrm{a}$ & 0.18 & Onshore \\
\hline \multicolumn{8}{|c|}{ SMT Parameters } \\
\hline $\begin{array}{l}\text { WIS } \\
\text { Station }\end{array}$ & $\begin{array}{l}\text { WIS } \\
\text { Depth } \\
\text { (m) }\end{array}$ & $\begin{array}{c}\text { Shoreline } \\
\text { Angle }\end{array}$ & $\begin{array}{l}\text { Assumed } \\
\text { Longshore } \\
\text { Current } \\
(\mathrm{m} / \mathrm{s})\end{array}$ & $\begin{array}{c}\text { Average } \\
\text { Wave } \\
\text { Height } \\
\text { (m) }\end{array}$ & $\begin{array}{l}\text { Average } \\
\text { Wave } \\
\text { Period (s) }\end{array}$ & $\begin{array}{l}\text { Wave } \\
\text { Vector } \\
\text { (deg) }\end{array}$ & $\begin{array}{l}\text { Average } \\
\text { Wind } \\
\text { Direction } \\
\text { (deg) }\end{array}$ \\
\hline 83107 & 848 & 6 & 0.1 & $1.0 *$ & $13 *$ & $267 *$ & $292 *$ \\
\hline
\end{tabular}

\subsubsection{SMT results}

Given that waves in this area are not particularly steep $(H / L=1 / 13)$, the bed shear stress criterion using linear wave theory for transport potential is more appropriate here compared to other sites (Figure 2-17). The critical 
shear stress for $0.18 \mathrm{~mm}$ sediment is $0.16 \mathrm{~Pa}$, which is predicted to have been exceeded by $75 \%$ of the waves for a placement depth of $11.5 \mathrm{~m}$ (Table 2-16), and in the onshore direction (Table 2-16). The predicted high sediment activity and shoreward migration matches the monitoring observations.

Figure 2-17. Distribution of maximum bed shear stress (top) and near-bottom velocities (bottom) for site Ocean Beach, California (WIS station 83107). $N$ is the number of hourly wave heights in each bin during the monitoring period.

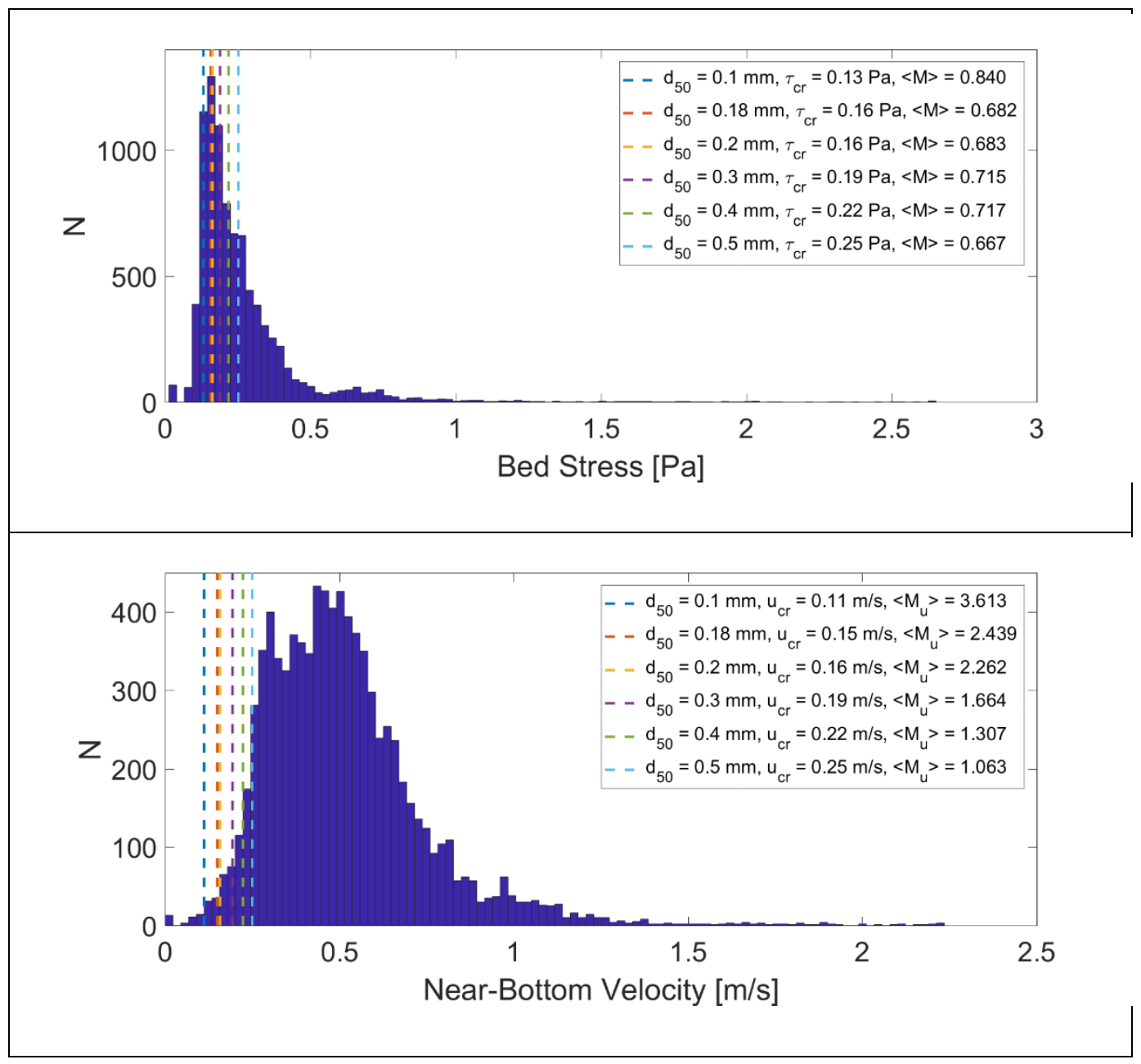


Table 2-16. Ocean Beach, California frequency of mobilization and predicted sediment migration for indicated grain sizes. The median grain size of placed material is shown in bold.

\begin{tabular}{|c|c|c|c|}
\hline $\begin{array}{c}\text { d50 } \\
(\mathbf{m m})\end{array}$ & $\begin{array}{c}\text { Bed Shear Stress } \\
\text { Mobilization }\left(\boldsymbol{F}_{\boldsymbol{M}}\right)\end{array}$ & $\begin{array}{c}\text { Near-Bottom Velocity } \\
\text { Mobilization }\left(\boldsymbol{F}_{\boldsymbol{M u}}\right)\end{array}$ & $\begin{array}{c}\text { Predicted Sediment } \\
\text { Migration }\end{array}$ \\
\hline 0.1 & $87 \%$ & $100 \%$ & $66 \%$ Onshore \\
\hline 0.18 & $74 \%$ & $99 \%$ & $98 \%$ Onshore \\
\hline 0.2 & $72 \%$ & $99 \%$ & $99 \%$ Onshore \\
\hline 0.3 & $73 \%$ & $97 \%$ & $100 \%$ Onshore \\
\hline 0.4 & $73 \%$ & $96 \%$ & $100 \%$ Onshore \\
\hline 0.5 & $71 \%$ & $93 \%$ & $100 \%$ Onshore \\
\hline
\end{tabular}

\subsection{Site 9: Fort Meyers Beach, Florida (2009)}

\subsubsection{Site description and berm construction}

In 2009, approximately $175,000 \mathrm{~m}^{3}$ (229,000 yd3) of dredged material was used to construct a linear berm offshore of Fort Meyers Beach at Estero Island (Figure 2-18). The island is a low-lying barrier and is part of the west-central barrier island chain along Florida's Gulf coast. Sediments for the berm were dredged from Matanzas Pass, a federally maintained waterway on the northern terminus of the island. The goal of the project was to nourish the beach with dredged material that contained a percentage of fines greater than that allowable by direct subaerial placement. The berm was placed in a disposal area approximately 100-200 m offshore in water depths ranging from 1.7 to $2.7 \mathrm{~m}$; distance to the berm crest varied from $68 \mathrm{~m}$ to $147 \mathrm{~m}$. The berm was approximately $1.6 \mathrm{~km}$ long and $120 \mathrm{~m}$ wide. It was noted that the berm was irregular in the longshore direction and multiple gaps existed along the berm crest (Wang et al. 2013). Natural bars in the foreshore of the area are typically small and ephemeral (Brutsche et al. 2014). The median grain size of the dredged material was $0.16 \mathrm{~mm}$ with a composite fines content of approximately 8 percent (Wang et al. 2013). 
Figure 2-18. Location map of placement site Fort Meyers Beach, Florida. Imagery courtesy of Google Earth. Image date 2016.

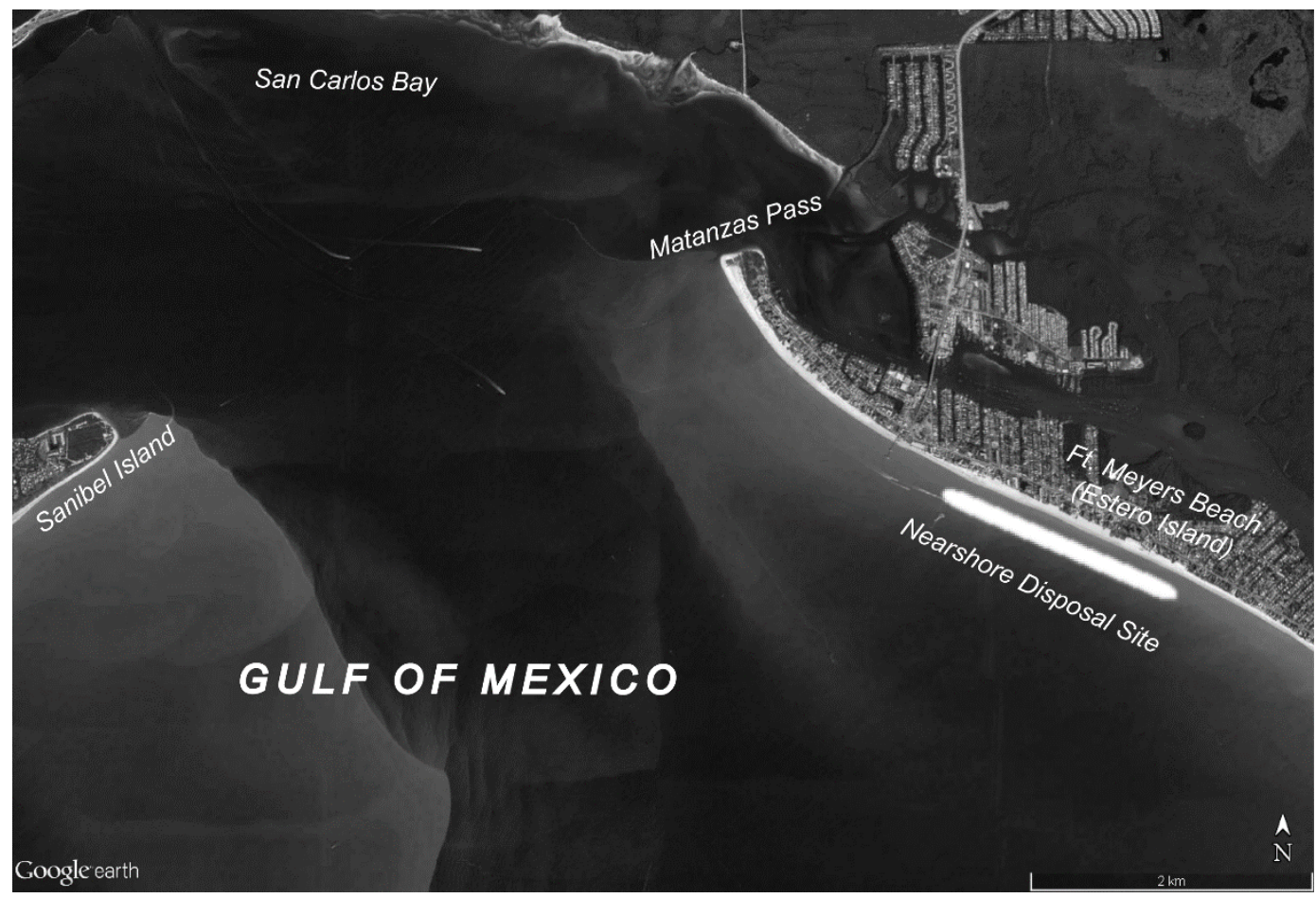

\subsubsection{Hydrographic description}

The offshore area is considered a low energy environment. Wave heights during summer months range from calm to $0.3 \mathrm{~m}$ with slightly higher waves during winter months from the passage of frontal systems (Brutsche et al. 2014). The protrusion of Sanibel Island on the opposite side of Matanzas Pass blocks waves approaching from the north and establishes a reversal in longshore sediment transport, which is to the north from the location of study area to the northern end of Estero Island $(3 \mathrm{~km})$, and southerly otherwise. Tides are mixed, with a neap tide range of $0.75 \mathrm{~m}$ and a spring tide range of $1.2 \mathrm{~m}$ (Brutsche et al. 2014). Summary characteristics are provided in Table 2-17.

\subsubsection{Monitoring and berm evolution}

Cross-shore surveys showed that the berm migrated landward rapidly during the first year and decreased thereafter and was likewise greater during winter months when waves were more energetic. The berm migrated $100 \mathrm{~m}$ in the first 2 years. Through the 4-year study duration, the nearshore profile had evolved back to its natural pre-construction equilibrium state, apparently accelerated by the passage of two extra- 
tropical storms. Approximately 10\% of the placed material volume was thought to have been captured on the beach (Brutsche et al. 2014). From sedimentological analyses, fine sediments were reported to have mostly winnowed out.

Table 2-17. Summary characteristics table for Fort Meyers Beach, Florida.

\begin{tabular}{|c|c|c|c|c|c|c|c|c|}
\hline \multicolumn{2}{|c|}{$\begin{array}{l}\text { Monitoring } \\
\text { Dates }\end{array}$} & \multicolumn{2}{|c|}{$\begin{array}{c}10 / 2009- \\
05 / 2013\end{array}$} & & & & & \\
\hline \multicolumn{2}{|c|}{$\begin{array}{c}\text { Placement } \\
\text { Volume }\left(\mathrm{m}^{3}\right)\end{array}$} & \multicolumn{2}{|c|}{$\begin{array}{l}\text { Berm Dimensions } \\
\quad(\mathrm{m})(\mathrm{I} \times \mathrm{w})\end{array}$} & & $\begin{array}{l}\text { Nater } \\
\text { Depth } \\
\text { (m) }\end{array}$ & $\begin{array}{l}\text { Berm } \\
\text { Relief } \\
\text { (m) }\end{array}$ & $\begin{array}{l}\text { Mean } \\
\text { Sand } \\
\text { Size } \\
(\mathrm{mm})\end{array}$ & $\begin{array}{l}\text { Observed } \\
\text { Berm } \\
\text { Migration }\end{array}$ \\
\hline \multicolumn{2}{|c|}{175,000} & \multicolumn{2}{|c|}{$1600 \times 120$} & & $.7-2.7$ & $0.2-0.9$ & 0.16 & Onshore \\
\hline \multicolumn{9}{|c|}{ SMT Parameters } \\
\hline $\begin{array}{l}\text { WIS } \\
\text { Station }\end{array}$ & $\begin{array}{l}\text { WIS Depth } \\
\text { (m) }\end{array}$ & $\begin{array}{c}\text { Shoreline } \\
\text { Angle }\end{array}$ & \multicolumn{2}{|c|}{$\begin{array}{l}\text { Assumed } \\
\text { Longshore } \\
\text { Current } \\
(\mathrm{m} / \mathrm{s})\end{array}$} & $\begin{array}{l}\text { Average } \\
\text { Wave } \\
\text { Height }(\mathrm{m})\end{array}$ & $\begin{array}{l}\text { Average } \\
\text { Wave } \\
\text { period (s) }\end{array}$ & $\begin{array}{l}\text { Wave } \\
\text { Vector } \\
\text { (deg) }\end{array}$ & $\begin{array}{l}\text { Average } \\
\text { Wind } \\
\text { Direction } \\
\text { (deg) }\end{array}$ \\
\hline 73295 & 5 & 298 & 0.0 & & 0.16 & 4 & 201 & 090 \\
\hline
\end{tabular}

\subsubsection{SMT results}

The SMT results (Figure 2-19) predict that the berm would be mobilized by $35 \%$ to $45 \%$ of the significant wave heights and will migrate onshore by $97 \%$ of the mobilizing waves for a median grain size of $0.125 \mathrm{~m}$ in a water depth of $2.2 \mathrm{~m}$ (Table 2-18). The mean mobility scores less than 1 generally indicate a stable berm, but it was noted in the observations that sediment migration was accelerated by extra-tropical storms. 
Figure 2-19. Distribution of maximum bed shear stress (top) and near-bottom velocities (bottom) for site Fort Meyers, Florida (WIS station 73259). $N$ is the number of waves in each bin during the monitoring period.

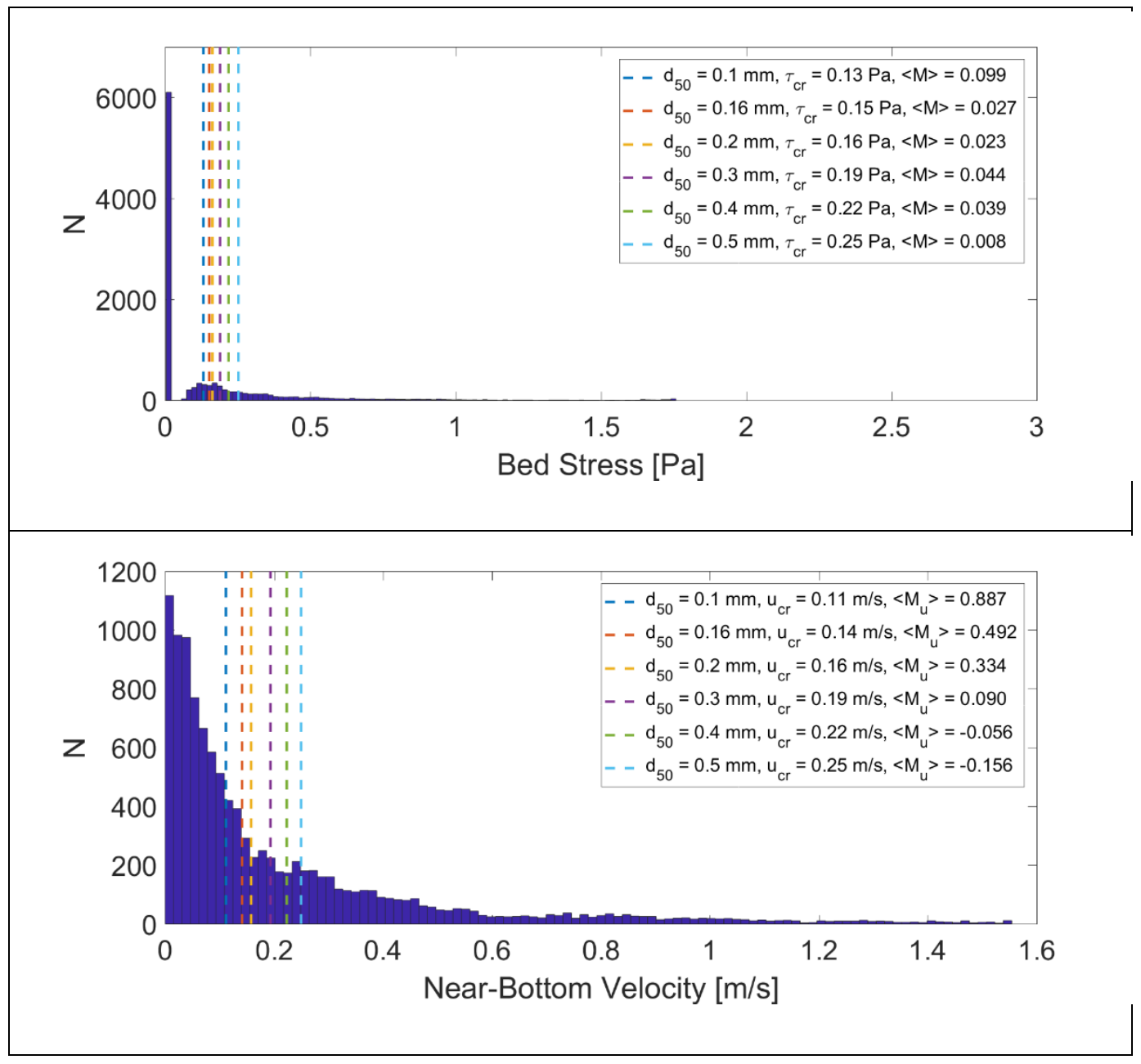

Table 2-18. Fort Meyers Beach, Florida frequency of mobilization and predicted sediment migration for indicated grain sizes. Median grain size of placed material in bold.

\begin{tabular}{|c|c|c|c|}
\hline $\begin{array}{c}\text { d50 } \\
(\mathbf{m m})\end{array}$ & $\begin{array}{c}\text { Bed Shear Stress } \\
\text { Mobilization }\left(\boldsymbol{F}_{\boldsymbol{M}}\right)\end{array}$ & $\begin{array}{c}\text { Near-Bottom Velocity } \\
\text { Frequency of } \\
\text { Mobilization }\left(\boldsymbol{F}_{\boldsymbol{M u}}\right)\end{array}$ & $\begin{array}{c}\text { Predicted Sediment } \\
\text { Migration }\end{array}$ \\
\hline 0.1 & $36 \%$ & $48 \%$ & $86 \%$ Onshore \\
\hline 0.125 & $35 \%$ & $45 \%$ & $97 \%$ Onshore \\
\hline 0.2 & $31 \%$ & $39 \%$ & $100 \%$ Onshore \\
\hline 0.3 & $28 \%$ & $34 \%$ & $100 \%$ Onshore \\
\hline 0.4 & $27 \%$ & $30 \%$ & $100 \%$ Onshore \\
\hline 0.5 & $27 \%$ & $27 \%$ & $100 \%$ Onshore \\
\hline
\end{tabular}




\section{Summary and Conclusions}

The SMT is used to rapidly assess the sediment mobility potential of nearshore berms as a function of water depth, wave height, and sediment diameter. Sediment mobility results from the SMT were compared to nine previously documented dredged material placement sites of both mound and linear berm geometries. The selected placement sites represented a range of energy conditions, placement depths, and grain sizes from three major water bodies. This broad spectrum of conditions allows for a more complete picture of the SMT's capabilities and limitations. For example, it was generally observed that the SMT performed well as a rapid, preliminary tool to estimate the behavior of the nearshore berms for the range of conditions tested. However, the potential for direct nourishment of the beach cannot be predicted with the SMT. Likewise, at this time the SMT should only be used for noncohesive sediments.

The SMT correctly predicted the sediment mobility and direction for eight of nine sites (Table 3-1). Most of the study sites were predicted by the SMT to have very high frequencies of mobility ( $>90 \%$ ), typically associated with relatively shallow placement depths and energetic conditions. Accordingly, there is relatively high confidence that the design considerations for those sites would mobilize and maintain sediment in the littoral zone. Conversely, observations at Dam Neck, Virginia, did not match SMT predictions (highlighted in Table 3-1). In this case, a berm composed of very fine sediment was placed in deeper water compared to other sites. The finer sediment size reduced the critical thresholds for mobility, and the SMT produced a high frequency of mobility when the berm was actually stable. The exact reason for the SMT's incorrect results is not fully understood, but the berm was constructed as a mound, which is not as effective in dissipating wave energy compared to linear berms as argued in the literature (Zwamborn et al. 1970; Frisch 1979; Gunyakti 1987) and may have wave focusing effects. Additionally, for the Dam Neck site, while the calculated frequencies of mobility were high ( $84 \%$ and $99 \%)$, the migration was predicted in the offshore direction, and the observations in the field noted that it was stable. This result underscores the notion that the SMT is a preliminary scoping tool and that large projects may warrant the use of high-level numerical models.

Mean mobility scores of less than one were observed in the SMT results for Mobile, Alabama, Perdido Key, Florida, and Fort Meyers, Florida. Mean 
mobility scores less than 1 generally note a stable berm as seen in Mobile, Alabama, and Perdido Key, Florida. The negative mean mobility scores at Mobile stresse the increased likelihood of a stable berm, likely due to its placement depth. Conversely, the nearshore berm at Fort Meyers, Florida, was noted to be in a very mild wave climate though may have increased sediment migration during passing storms.

The Perdido Key project (1991) is a good example of how the SMT could have been used to inform decisions about nearshore placement during the project planning phase. From a planning perspective, such low frequency of mobility and low mean mobility score values would have warranted re-evaluation of the design considerations and placement depth for the expected wave climate. Thus, considerable value is gained by the ability to apply a rapid, simple tool to evaluate potential outcomes against various project scenarios.

Table 3-1. Summary of SMT berm migration results compared to observations.

\begin{tabular}{|c|c|c|c|c|c|c|c|c|c|}
\hline \multirow[b]{2}{*}{$\begin{array}{l}\text { Placement } \\
\text { Site }\end{array}$} & \multirow[b]{2}{*}{ Year } & \multirow[b]{2}{*}{ Geometry } & \multirow[b]{2}{*}{$\begin{array}{c}\text { Depth } \\
(\mathrm{m})\end{array}$} & \multirow{2}{*}{$\begin{array}{c}\text { Berm } \\
\text { Relief } \\
(\mathrm{m})\end{array}$} & \multirow[b]{2}{*}{$\begin{array}{c}d_{50} \\
(\mathrm{~mm})\end{array}$} & \multicolumn{3}{|c|}{ SMT Results } & \multirow[b]{2}{*}{$\begin{array}{l}\text { Observed } \\
\text { Migration }\end{array}$} \\
\hline & & & & & & $F_{M}$ & $F_{M u}$ & $\begin{array}{l}\text { Predicted } \\
\text { Migration }\end{array}$ & \\
\hline $\begin{array}{c}\text { Dam Neck, } \\
\text { VA }\end{array}$ & 1982 & Mound & 11 & 3.3 & 0.08 & $84 \%$ & $99 \%$ & $\begin{array}{c}88 \% \\
\text { Offshore }\end{array}$ & Stable \\
\hline Mobile, AL & 1988 & $\begin{array}{l}\text { Irregular } \\
\text { mound }\end{array}$ & $\begin{array}{l}10.6- \\
13.7\end{array}$ & 6.6 & 0.25 & $8 \%$ & $17 \%$ & $\begin{array}{c}84 \% \\
\text { Offshore }\end{array}$ & Stable \\
\hline $\begin{array}{c}\text { Silver } \\
\text { Strand, CA }\end{array}$ & 1988 & Berm & $\begin{array}{l}4.8- \\
8.5\end{array}$ & 2.1 & 0.25 & $100 \%$ & $100 \%$ & $\begin{array}{c}100 \% \\
\text { Onshore }\end{array}$ & Onshore \\
\hline $\begin{array}{c}\text { Port } \\
\text { Canaveral, } \\
\text { FL }\end{array}$ & 1992 & Berm & $\begin{array}{l}5.5- \\
7.0\end{array}$ & 1.6 & 0.44 & $97 \%$ & $99 \%$ & $\begin{array}{c}100 \% \\
\text { Onshore }\end{array}$ & Onshore \\
\hline $\begin{array}{l}\text { Perdido } \\
\text { Key, FL }\end{array}$ & 1991 & Berm & $\begin{array}{l}5.0- \\
6.5\end{array}$ & 1.75 & 0.28 & $36 \%$ & $47 \%$ & $\begin{array}{c}99 \% \\
\text { Onshore }\end{array}$ & Stable \\
\hline $\begin{array}{l}\text { Newport } \\
\text { Beach, CA }\end{array}$ & 1992 & $\begin{array}{l}\text { Multiple } \\
\text { mounds }\end{array}$ & 5.5 & 4.4 & 0.27 & $60 \%$ & $98 \%$ & $\begin{array}{c}100 \% \\
\text { Onshore }\end{array}$ & Onshore \\
\hline $\begin{array}{c}\text { Brunswick, } \\
\text { GA }\end{array}$ & 2003 & Mound & 6 & $4-5$ & 0.35 & $97 \%$ & $99 \%$ & $\begin{array}{c}100 \% \\
\text { Onshore }\end{array}$ & Onshore \\
\hline $\begin{array}{c}\text { Ocean } \\
\text { Beach, CA }\end{array}$ & 2005 & $\begin{array}{l}\text { Irregular } \\
\text { mound }\end{array}$ & 11.5 & - & 0.18 & $75 \%$ & $100 \%$ & $\begin{array}{c}98 \% \\
\text { Onshore }\end{array}$ & Onshore \\
\hline $\begin{array}{c}\text { Fort } \\
\text { Meyers, FL }\end{array}$ & 2009 & Berm & $\begin{array}{l}1.7- \\
2.7\end{array}$ & $\begin{array}{l}0.2- \\
0.9\end{array}$ & 0.125 & $35 \%$ & $45 \%$ & $\begin{array}{c}97 \% \\
\text { Onshore }\end{array}$ & Onshore \\
\hline
\end{tabular}




\section{References}

Ahrens, J. P., and E. B. Hands. 1998. "Velocity Parameters for Predicting Cross-Shore Sediment Movement." Journal of Waterways, Ports, Coastal, and Ocean Engineering 124(1): 16-20.

Allison, M. C., and C. B. Pollock. 1993. "Nearshore Berms: An Evaluation of Prototype Designs." Proceedings, $8^{\text {th }}$ Symposium on Coastal and Ocean Management, New Orleans, Louisiana, July 19-23.

Andrassay, C. J. 1991. "Monitoring of a Nearshore Disposal Mound at Silver Strand State Park.” Proceedings, Coastal Sediments '91, American Society of Civil Engineers, 1970-1984.

Barnard, P. L., D. M. Hanes, J. Lescinski, and E. Elias. 2006. Monitoring and Modeling Nearshore Dredge Material Disposal for Indirect Beach Nourishment, Ocean Beach, San Francisco. Open-File Report 2006-1140. US Geological Survey. http://pubs.usgs.gov/of/2006/1140/

Barnard, P. L., D. M. Hanes, J. Lescinski, and E. Elias. 2009. The Performance of Nearshore Dredge Disposal at Ocean Beach, San Francisco, California, 20052007. Open-File Report 2008-1347. US Geological Survey. https://pubs.usgs.gov/of/2008/1347/

Bodge, K. R. 1994. Proceedings, Dredging '94, American Society of Civil Engineers, Orlando, Florida, November 13-16, 1994.

Browder, A. E., and R. G. Dean. 1999. "Coastal impacts of the Pensacola Pass Entrance, FL, USA.” Proceedings, Coastal Sediments '99, Reston, Virginia, ASCE. Edited by N. C. Kraus and W. G. McDougal, 719-733.

Brutsché, K. E., P. Wang, T. M. Beck, J. D. Rosati, and K. R. Legault. 2014. "Morphological Evolution of a Submerged Artificial Nearshore Berm along a Low-Wave Microtidal Coast, Fort Meyers Beach, West-central Florida, USA.” Coastal Engineering 91: 29-44.

Burke, C. E., and M.C. Allison. 1992. Length and End Slope Considerations, Interim Design Guidance Update for Nearshore Berm Construction. DRP-5-06. Vicksburg, MS: US Army Engineer Waterways Experiment Station.

CBRS (California Department of Boating and Waterways and State Coastal Conservancy. 2002. California Beach Restoration Study. Sacramento, California.

Dean, R. G. 1974. Evaluation and Development of Water Wave Theories for Engineering Applications; Volume I-Presentation of Research Results; Volume II-Tabulation of Dimensionless Stream-Function Variables. Special Report No. 1. Fort Belvoir, VA: Coastal Engineering Research Center.

DeLoach, S. R. 1985. Analysis of a Dredged Material Disposal Operation. Dam Neck Ocean Disposal Site, Virginia. Report B-47. US Army Corps of Engineers, Norfolk District. 
Douglass, S. L. 1995. "Estimating landward migration of nearshore constructed sand mounds." Journal of Waterway, Port, Coastal, and Ocean Engineering 121(5): 247-250.

Frisch, A. A. 1979. A Model Study of the Effects of Bathymetry Alterations on Shoreline Wave Energy Distribution. Master's thesis, College of William and Mary, Williamsburg, VA.

Galvin, C. J., and R. A. Nelson. 1967. Compilation of Longshore Current Data. Miscellaneous Paper 2-67. Washington, DC: US Army Coastal Engineering Research Center.

Gunyakti, A. 1987. "Beach Preservation by Means of Offshore Submerged Mound of Dredged Materials.” Proceedings of the Conference Coastal Zone '87, American Society of Engineers, New York, 2461-2471.

Hall, J. V., and W. J. Herron. 1950. Test of Nourishment of the Shore by Offshore Deposition of Sand, Long Branch, New Jersey. Technical Memorandum No. 17. US Army Corps of Engineers Beach Erosion Board.

Hall, J. V., and G. M. Watts. 1957. "Beach Rehabilitation by Fill and Nourishment." Transactions of the American Society of Civil Engineers. Paper 2853, 155-177.

Hallermeier, R. J. 1981a. "Terminal Settling Velocity of Commonly Occurring Sand Grains.” Journal of Sedimentology 28: 259-865.

Hallermeier, R. J. 1981b. Seaward Limit of Significant Sand Transport by Waves: An Annual Zonation for Seasonal Profiles. Coastal Engineering Technical Aid 81-2. Vicksburg, MS: Coastal Engineering Research Center.

Hands, E. B., and M.C. Allison. 1991. "Mound Migration in Deeper Water and Methods of Categorizing Active and Stable Depths." Proceedings of Coastal Sediments ' 91 , American Society of Civil Engineers, 1985-1999.

Hands, E. B., and S. R. DeLoach. 1984. "An Offshore Mound Constructed of Dredged Material. Dredging and Dredged Material Disposal.” Proceedings of the Conference Dredging 84, American Society of Civil Engineers, NY, 1030-1039.

Harris, R. L. 1954. Restudy Of Test-Shore Nourishment by Offshore Deposition of Sand, Long Branch, New Jersey. Technical Memorandum No. 62. US Army Corps of Engineers Beach Erosion Board.

Inman, D. L. 1976. “Man's Impact on the California Coastal Zone.” Sacramento, California Department of Navigation and Ocean Development.

Johnson, C. R. 2005. Migration of Dredged Material Mounds: Prediction Based on Field Measurements of Waves, Currents, and Suspended Sediments, Brunswick, Georgia. MS thesis, School of Civil and Environmental Engineering, Georgia Institute of Technology, Atlanta, Georgia.

Jones, S. C., and P. Patterson. 2006. Gulf of Mexico 2005 Beach Topographic Monitoring and Shoreline Change Analysis, Baldwin and Mobile Counties, Alabama. Open-File Report 2006-0613. Alabama Geological Survey. 
Juhnke, L., T. Mitchell, and M. J. Piszker. 1990. Construction and Monitoring of Nearshore Placement of Dredged Material at Silver Strand State Park, San Diego, California. DRP-1-01. Vicksburg, MS: US Army Engineer Waterways Experiment Station.

Kraus, N. C. 1992. Prediction of Cross-Shore Movement of Dredged Material Berms. DRP-1-09. Vicksburg, MS: US Army Engineer Waterways Experiment Station.

Larson, M., N. C. Kraus, and M. R. Byrnes. 1989. SBEACH: Numerical Model for Simulating Storm-Induced Beach Change; Report 2: Numerical Formulation and Model Tests. Technical Report CERC-89-9. Waterways Experiment Station, Vicksburg, MS.

Larson, M., and N. C. Kraus. 1992. Analysis of Cross-Shore Movement of Natural Longshore Bars and Material Placed to Create Longshore Bars. Technical Report DRP-92-5. Vicksburg, MS: Waterways Experiment Station.

McAneny, D. S. 1986. Sea-State Engineering Analysis System (SEAS) Supplement I, WIS Report 1O. Vicksburg, MS: US Army Engineer Waterways Experiment Station.

McArthur, C. J., and M. Parsons. 2005. Ocean Current and Wave Measurements at the Canaveral Harbor Ocean Dredge Material Disposal Site. Survey Report EPA904-R-05-001. Atlanta, GS: US Environmental Protection Agency, Region 4.

McFall, B. C., and K. E. Brutsché. 2018. User's Guide for the Sediment Mobility Tool Web Application. ERDC/TN RSM-18-4. Vicksburg, MS: US Army Engineer Research and Development Center.

McFall, B. C., C. E. Pollock, and K. E. Brutsché. 2015. Evaluating Sediment Mobility for Milford, CT Nearshore Placement. ERDC/CHL LR 15-7. Vicksburg, MS: US Army Engineer Research and Development Center.

McFall, B. C., S. J. Smith, C. E. Pollock, J. Rosati, III, and K. E. Brutsché. 2016. Evaluating Sediment Mobility for Siting Nearshore Berms. ERDC/CHL CHETNIV-108. Vicksburg, MS: US Army Engineer Research and Development Center.

McGehee, D. D., J. P. McKinney, W. E. Grogg, and E. B. Hands. 1994. Monitoring of Waves and Currents near the Alabama Dredged Material Mounds. Technical Report DRP-94-4. Vicksburg, MS: US Army Engineer Waterways Experiment Station.

McLellan, T. N., C. L. Truitt, and P. D. Flax. 1988. "Nearshore Placement Techniques for Dredged Material." Proceedings, $21^{\text {st }}$ Annual Dredging Seminar, Texas A\&M University, College Station, TX, 24-35.

McLellan, T. N., and F. D. Imsand. 1989. "Berm Construction Utilizing Dredged Material.” Proceedings of WODCON XII, World Dredging Congress 1989, Orlando, Florida, USA.

McLellan, T. 1990. Engineering Design Considerations for Nearshore Berms. DRP-5-01. Vicksburg, MS: US Army Engineer Waterways Experiment Station. 
McLellan, T. N., N. C. Kraus, and C. E. Burke. 1990. Interim Design Guidance for Nearshore Berm Construction. DRP-5-02. Vicksburg, MS: US Army Engineer Waterways Experiment Station.

McLellan, T. N., and N. C. Kraus. 1991. "Design Guidance for Nearshore Berm Construction." Proceedings of Coastal Sediments '91, American Society of Civil Engineers, 2000-2011.

Mesa, C. 1997. "Nearshore Berm Performance at Newport Beach, California, USA." Proceedings of Coastal Engineering 1996, American Society of Civil Engineers.

Myrhaug, D. 1989. "A Rational Approach to Wave Friction Coefficients for Rough, Smooth, and Transitional Turbulent Flow." Coastal Engineering 24: 259-273.

Otay, E. N. 1994. Long-Term Evolution of Nearshore Disposal Berms. Ph.D. Dissertation, Coastal and Oceanographic Engineering Department, University of Florida, Gainesville, FL.

Patsch, K., and G. Griggs. 2007. Development of Sand Budgets for California's Major Littoral Cells. Institute of Marine Sciences, University of California, Santa Cruz Coastal Sediment Management Workgroup.

Pollock, C. B., and M. C. Allison. 1993. Berm Crest Width Considerations, Interim Design Guidance Update for Nearshore Berm Construction. DRP-5-08. Vicksburg, MS: US Army Engineer Waterways Experiment Station.

Smith, S. J., J. Marsh, and T. Puckette. "Analysis of Fluorescent Sediment Tracer for Evaluating Nearshore Placement of Dredged Material." Proceedings of WODCON XVIII, World Dredging Congress 2007, Lake Buena Vista, Florida, USA.

Soulsby, R. L. 1997. Dynamics of Marine Sands. London: Thomas Telford Publications.

Tyler, Z. J., B. C. McFall, K. E. Brutsché, E. C. Maloney, and D. K. Bucaro, 2018. Physical Monitoring Methods for the Nearshore Placement of Dredged Sediment. ERDC/TN RSM-18-6. Vicksburg, MS: US Army Engineer Research and Development Center. http://dx.doi.org/10.21079/11681/26661

Wang, P., K. E. Brutsché, J. W. Lagrone, T. M. Beck, J. D. Rosati, L. S. Lillycrop. 2013. Performance Monitoring of a Nearshore Berm at Fort Myers Beach, Florida: Final Report. ERDC/CHL TR-13-11. Vicksburg, MS: US Army Engineer Research and Development Center.

Wiegel, R. L. 2009. San Pedro Bay Delta, in Southern California Shore and Shore Use Changes during Past 1-1/2 Centuries from a Coastal Engineering Perspective. Hydraulic Engineering Laboratory Report UCB/HEL 2009-2. University of California, Berkeley.

Zwamborne, J. A., G. A. W. Fromme, and J. B. FitzPatrick. 1970. "Underwater Mound for the Protection of Durban's Beaches." Proceedings, $12^{\text {th }}$ Coastal Engineering Conference, American Society of Civil Engineers, NY. 


\section{Acronyms and Abbreviations}

$\begin{array}{ll}\text { cm } & \text { centimeter } \\ \text { deg } & \text { degree } \\ \text { DRP } & \text { Dredging Research Program } \\ \text { km } & \text { kilometer } \\ \text { m } & \text { meter } \\ \text { m/s } & \text { meter per second } \\ \text { m3 } & \text { cubic meter } \\ \text { MLLW } & \text { mean lower low water } \\ \text { MLW } & \text { mean low water } \\ \text { mm } & \text { millimeter } \\ \text { MOM } & \text { Mobile Outer Mound } \\ \text { NAE } & \text { New England District } \\ \text { Pa } & \text { Pascal } \\ \text { S } & \text { second } \\ \text { SMT } & \text { Sediment Mobility Tool } \\ \text { USACE } & \text { US Army Corps of Engineers } \\ \text { WIS } & \text { Wave Information Studies }\end{array}$




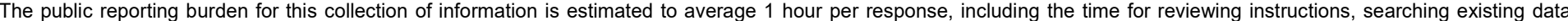

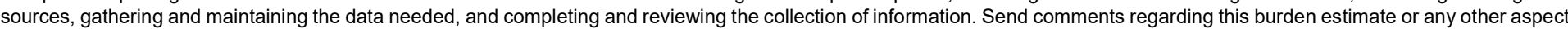

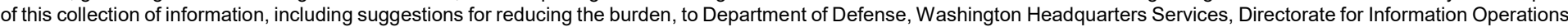

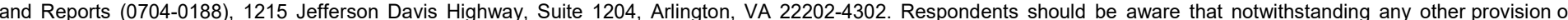
law, no person shall be subject to any penalty for failing to comply with a collection of information if it does not display a currently valid OMB control number.

PLEASE DO NOT RETURN YOUR FORM TO THE ABOVE ADDRESS.

\begin{tabular}{l|l|l}
\hline 1. REPORT DATE & 2. REPORT TYPE \\
December 2019 & Final Report
\end{tabular}

\section{TITLE AND SUBTITLE}

Performance of Nearshore Berms from Dredged Sediments: Validation of the Sediment

Mobility Tool 5a. CONTRACT NUMBER

5b. GRANT NUMBER

5c. PROGRAM ELEMENT NUMBER

6. AUTHOR(S)

Anthony M. Priestas, Brian McFall, and Katherine E. Brutsché 5d. PROJECT NUMBER

5e. TASK NUMBER

5f. WORK UNIT NUMBER

8. PERFORMING ORGANIZATION REPORT NUMBER

TR-19-19

10. SPONSOR/MONITOR'S ACRONYM(S) CIRP

11. SPONSOR/MONITOR'S REPORT NUMBER(S)

Vicksburg, MS 39180-6199

\section{DISTRIBUTION/AVAILABILITY STATEMENT}

Approved for public release; distribution is unlimited.

\section{SUPPLEMENTARY NOTES}

Funding Acct Code U4362900, AMSCO Code 060000

\section{ABSTRACT}

The construction of artificial berms in the nearshore environment using dredged material has been in practice since the 1930s. While considerable progress has been achieved from both theoretical and practical considerations, placement decisions were often heuristic, based on experience, or required tedious calculations. For that reason, the Sediment Mobility Tool (SMT) was developed to make rapid, preliminary assessments of nearshore placement areas and berm migration.

This technical report provides a comparative analysis between SMT results and historical field observations for nine nearshore placement projects with diverse berm geometries, sediment characteristics, and wave climates.

The SMT correctly predicted nearshore berm sediment mobility and migration directions for eight of the nine historical berms studied. These sites were typically associated with shallow placement depths and energetic wave conditions. Likewise, the SMT correctly predicted stable berms for two of three sites. For one case in particular, the SMT correctly predicted a stable berm in contrast to the expectation that the berm would mobilize, which underscores the value of SMT to make informed decisions during project planning. The few discrepancies between SMT predictions and observations may be partly explained by berm geometry (mound versus linear berm), whereby application of the tool to mounded geometries may not be suitable.

\section{SUBJECT TERMS}

Beach nourishment, Coastal sediments, Hydraulic models, Hydrodynamics, Littoral drift, Sedimentation and deposition, Sediment transport, Shore protection, Water currents, Water waves

\begin{tabular}{|c|c|c|c|c|c|}
\hline \multicolumn{3}{|c|}{ 16. SECURITY CLASSIFICATION OF: } & \multirow{3}{*}{$\begin{array}{l}\text { 17. LIMITATION OF } \\
\text { ABSTRACT } \\
\text { SAR }\end{array}$} & \multirow{3}{*}{$\begin{array}{l}\text { 18. NUMBER } \\
\text { OF } \\
\text { PAGES } \\
63\end{array}$} & \multirow{2}{*}{$\begin{array}{l}\text { 19a. NAME OF RESPONSIBLE PERSON } \\
\text { Anthony M. Priestas }\end{array}$} \\
\hline & & & & & \\
\hline Unclassified & Unclassified & Unclassified & & & $\begin{array}{l}\text { 19b. TELEPHONE NUMBER (Include area code) } \\
\text { 601-634-2978 }\end{array}$ \\
\hline
\end{tabular}

